\title{
Drawing borders: the political and symbolic importance of the United States in the creation of Czechoslovakia
}

\author{
Samantha Borgeson \\ West Virginia University
}

Follow this and additional works at: https://researchrepository.wvu.edu/etd

\section{Recommended Citation}

Borgeson, Samantha, "Drawing borders: the political and symbolic importance of the United States in the creation of Czechoslovakia" (2014). Graduate Theses, Dissertations, and Problem Reports. 342.

https://researchrepository.wvu.edu/etd/342

This Thesis is protected by copyright and/or related rights. It has been brought to you by the The Research Repository @ WVU with permission from the rights-holder(s). You are free to use this Thesis in any way that is permitted by the copyright and related rights legislation that applies to your use. For other uses you must obtain permission from the rights-holder(s) directly, unless additional rights are indicated by a Creative Commons license in the record and/ or on the work itself. This Thesis has been accepted for inclusion in WVU Graduate Theses, Dissertations, and Problem Reports collection by an authorized administrator of The Research Repository @ WVU. For more information, please contact researchrepository@mail.wvu.edu. 


\title{
DRAWING BORDERS: THE POLITICAL AND SYMBOLIC IMPORTANCE OF THE UNITED STATES IN THE CREATION OF CZECHOSLOVAKIA
}

\section{Samantha Borgeson}

\author{
Thesis submitted to the \\ Eberly College of Arts And Sciences \\ at West Virginia University \\ in partial fulfillment of the requirements \\ for the degree of
}

Master of Arts in History

Robert Blobaum, PhD., Chair

Katherine Aaslestad, PhD.

James Siekmeier, PhD.

Department of History

Morgantown, West Virginia

2014

Key Words: Czechoslovakia; Czech Immigrants in America; Woodrow Wilson and Czechoslovakia; Tomáš Masaryk; Czech Independence; America and Czechoslovakia; historic right; self-determination; Czech nationalism 


\section{Abstract \\ Drawing Borders: The Political and Symbolic Importance of the United States in the Creation of Czechoslovakia}

\section{by Samantha Borgeson}

In 2011, a statue of Woodrow Wilson, based on the original erected in 1928, was re-installed at Woodrow Wilson Train Station in the capital of the Czech Republic. The original statue commemorated Wilson's involvement in the creation of interwar Czechoslovakia, and his support for its independence. It also symbolized the democratic ideals which brought the two nations together following the Great War. Woodrow Wilson played a major part in the history and memory of Czechs during their formative years of their state following World War I, a role which has not been forgotten. Today the Wilson statue is the site of ongoing political and national memory construction revealing the multi-layered aspects of Czech national identity and politics.

There are three main components to the Czech-American relationship: the importance of the Czech argument of historic right to land, the role of Czech and Slovak immigrant groups in the United States in pressuring the Wilson Administration, and Wilson's worldview and idea of national self-determination Often interdependent, these three themes help explain the dual founding fathers myth of Czechoslovakia of Wilson and Masaryk, as well as the importance of this relationship in the present. 


\section{DEDICATION}

For my Grandfather, Dr. Donald Edward Pisar, "Grandaddy" 


\section{ACKNOWLEDGMENTS}

I'd like to thank my patient husband Eric McCall for putting up with many long hours spent on this thesis and during my time in the Atlantis program at West Virginia University. I would also like to thank everyone, especially my colleagues, who helped with input or just let me talk my ideas out. You all made this paper possible. I would not have pursued this degree without the unfailing encouragement and support of Professor Dawn Alexander-Payne during my time at Abilene Christian University and particularly after. For her support and assistance I am especially grateful.

I would also like to thank Professor Katherine Aaslestad for her invaluable input and comments on this thesis and Professor James Seikemeir for his assistance with the U.S. foreign policy and Woodrow Wilson angle of the thesis. Finally, thank you to my committee chair, Professor Blobaum, for not only giving me a chance to be a part of this amazing program at West Virginia University, but also for all the valuable input and comments on this thesis.

Thank you to my parents, Chuck Borgeson and Susan Tuerck, for constantly supporting my decisions even if it takes me far away from them and for their encouragement. I dedicate this work to my grandfather, Dr. Donald Edward Pisar. I realize how fortunate I am to have someone who took the time to share his love of history and heritage with me. Grandaddy is one of those 
descendents of Czech immigrants which my thesis discusses, who held onto his heritage and passed it on to his children and grandchildren. It is his Czech postcards which are in the appendix. Thank you for instilling in me a passion for history and an interest in all things Czech. 


\section{Table of Contents}

ABSTRACT

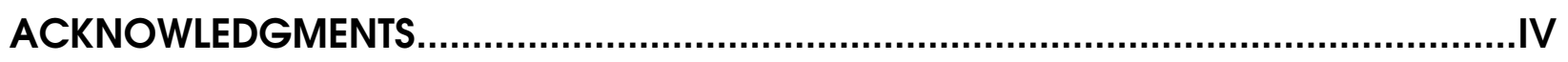

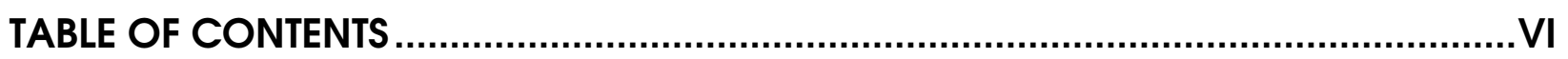

INTRODUCTION: WILSON'S INFLUENCE AND MEMORY …........................................ 1

CHAPTER 1 LEGITIMIZATION OF HISTORIC RIGHT IN THE CZECH LANDS ................... 13

CHAPTER 2 INFLUENCE OF IMMIGRANT GROUPS AND PERSONAL CONNECTIONS 37 CHAPTER 3 SELF-DETERMINATION: WILSON'S POLICIES TOWARD THE CZECHS

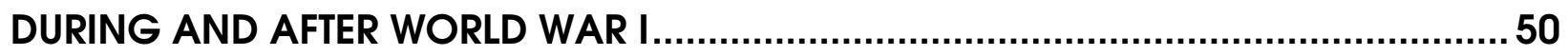

CHAPTER 4 CASE STUDY: WILSON IN CZECH MEMORY AND MONUMENTAL POLITICS 70

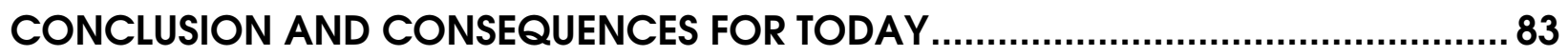

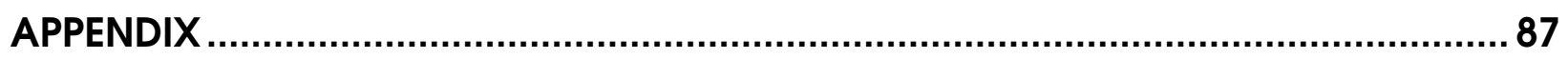

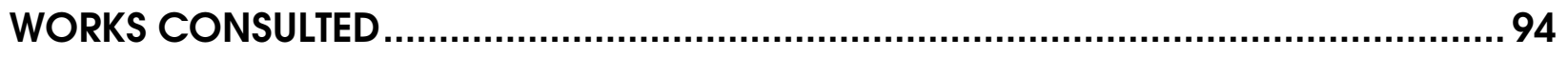




\section{Introduction: Wilson's Influence and Memory}

In 2011, a statue of Woodrow Wilson, based on the original erected in 1928, was re-installed at Woodrow Wilson Train Station in the capital of the Czech Republic. The original statue commemorated Wilson's involvement in the creation of interwar Czechoslovakia, and his support for its independence. It also symbolized the democratic ideals which brought the two nations together following the Great War. After the Czech state ceased to exist in 1939, the National Socialists occupation government led by Reinhard Heydrich destroyed the statue on December 12 1 th 1941 . Revealing the importance of the restoration of Wilson's statue in Prague, a Czech citizen declared, "Bringing President Wilson back to Central Europe is historic, and symbolic. It underscores the 'rule of law' and the Western style of democracy that started in 1918 in this part of the world." 1 This sentiment demonstrates that the symbol of Wilson continues to resonate throughout Czech society today. Indeed, throughout the new Czech Republic, there are numerous monuments, streets, train stations, and squares named after the American president. Woodrow Wilson played a major part in the history and memory of Czechs during their formative years of their state

\footnotetext{
1 Eileen Daday, "Local Czechs Proud of Wilson Statue," The Daily Herald, October 8, 2011.
} 
following World War I, a role which has not been forgotten. Today the Wilson statue is the site of ongoing political and national memory construction revealing the multi-layered aspects of Czech national identity and politics. An examination of the bond between Wilson and the Czechs reveals not only the deep connection between the former Czechoslovakia, the United States, and its former president to Czech history and identity but how these sites of memory continue to impact Czech foreign relations strategies and the special relationship between the United States and the Czech Republic.

At the end of World War I the Habsburg Monarchy, which had ruled various parts of Europe for over 600 years, disintegrated and in the aftermath numerous different ethnic groups struggled to create and maintain successorstates. The champion of one of these states, Tomáš Garrigue Masaryk of Czechoslovakia and later its first president, worked tirelessly during World War I to achieve recognition of this new state and support from the Allied powers. The success of his goals for independence and security of specific borders hinged on both President Woodrow Wilson of the United States and fervent support from Czech and Slovak immigrant groups in America. Masaryk's realization of an independent homeland was contingent on the interlocking doctrines of Wilson's principles of self-determination and democracy and Masaryk's argument of historic and ethnic rights for the creation of a Czechoslovak state as well as the influence of immigrant groups in the United States. 
In the aftermath of the collapse of the Austro-Hungarian Empire, several emerging nations employed history to legitimize border and statehood claims. Czechs employed an argument of historic right, among others, in order to establish (or re-establish according to this argument), a state with certain borders and on this basis they petitioned the Allied powers, including the United States, to accomplish this goal. Woodrow Wilson's policy of national selfdetermination largely legitimized this argument of historic right, and gave Central European nations an international platform from which to justify their border and statehood claims. The manipulation of the historical record to enhance one ethnic group over another led to unique characteristics in the emergence of new Central European states after 1919. Some of these characteristics include continuing to manipulate history in order to achieve state goals in the present as well as history playing a role in governmental policy decisions. The continuing importance of Wilson to the Czech Republic is a case in point.

The influence of immigrants in the United States on American foreign policy and in the realization of Czechoslovak statehood in 1918 underpinned Wilson's rhetoric of self-determination and overt support of the formation of a Czechoslovakian state. These immigrants continued to support their former homelands by forming civil society groups and lobbying President Wilson on behalf of Czecho-Slovak independence. Immigrant groups played an 
important role in the early twentieth century and continue to influence United States foreign policy today.

Along with President Wilson's support and the impact of the immigrant Czech-Slovak immigrant societies, ties between the two countries were also forged on a more personal basis. Tomáš Masaryk's wife was from Brooklyn and he was a personal friend of Charles Crane, a wealthy American businessman, former diplomat and staunch supporter of Woodrow Wilson. These political, societal, and personal ties proved to be the beginning of a long-term connection between the Czechs and Americans, kept alive by a celebration of shared democratic principles as well as by the immigrant heritage. Many cities in the United States still retain a large number of self-conscious Bohemian and Moravian Czech descendants. In addition, some still maintain close ties with the Czech Republic. As recently as 2013, the Czech government gave the town of West, Texas, comprised of nearly $75 \%$ Czech descendants, $\$ 200,000$ in order to rebuild its local sokol, or gymnasium, destroyed in a fertilizer plant explosion. The explosion caught the attention of the Czech Republic and was all over Czech news stations at the time. That the Czech government decided to donate this money to West represents importance of former immigrants to the Czech Republic as a means to continue nurturing good relations with the United States and with its former people. 
Let me add here a few definitions for the sake of simplicity and continuity. Throughout the thesis, I use the term "Bohemian lands" to discuss the ethnically diverse region which includes Bohemia and Moravia; basically, the boundaries of today's Czech Republic which encompasses almost the same territory as a tenth-century Bohemia. The term Czecho-Slovak is used to discuss shared war aims before statehood, whereas Czechoslovakia refers to the state which existed from 1918 to 1993 , excluding the time during the years of the Second World War when that state was divided, partitioned, and occupied by Nazi Germany and its allies.

Although a discussion of the Carpathian Rus or developments in Slovakia (aside from explaining how the Czechs framed the argument justifying the inclusion of Slovakia in a larger Czechoslovak state after World War I) will not be included in my discussion, this is not meant to diminish or marginalize their historical importance; they are topics best covered in another work. In Slovakia in particular, the region had a separate and distinct set of historical circumstances which do not fit into the crafted Bohemian historical narrative; consequently, the border disputes between Czechoslovakia and Hungary will be omitted.

There was a hope that a common Czecho-Slovak identity would eventually emerge. However, both nationalism and conflicting interests prevented the two sides from coming to terms and eventually the country broke 
apart in 1993.2 Czech nationalists had a Czechoslovak vision for the new state, and Slovak nationalists wanted exclusive home rule and independent government structures in their part of the new country. To some extent, Slovaks did attain home rule; however, Czech nationals emerged victorious when reforms encouraged common national identity among Czechs and Slovaks during the First Republic of Czechoslovakia (1918-1938). This difference of opinion on the new government caused deep divisions amongst leaders of the two groups which eventually led to the breakup of Czechoslovakia. ${ }^{3}$

There are three main components to the Czech-American relationship which can help explain the influence and impact of the United States in the founding of Czechoslovakia. The first theme is the importance of the Czech argument of historic right to land to convince the United States on the validity of Bohemian "historic nationhood." The second component to understanding early US-Czech relations is the Czech and Slovak immigrant groups in the United States and their role in pressuring the Wilson Administration. Finally, Wilson's worldview on national self-determination that developed in the context of the violence and destruction of the Great War represents a key theme in uncovering US support for the Czechoslovak state. Often interdependent, these

\footnotetext{
2 On Czech-Slovak relations, see Carol Skalnik Leff, The Czech and Slovak Republics: Nation Versus State (Boulder: Westview Press, 1997).

3 Robert Henry Cox and Erich G. Frankland, "The Federal State and the Breakup of Czechoslovakia: An Institutional Analysis," Publius 25, no 1 (Winter, 1995), 75-76.
} 
three themes help explain the dual founding fathers myth of Czechoslovakia of Wilson and Masaryk, as well as the importance of this relationship in the present.

Chapter One examines the first theme by exploring the Czech argument of historic right to contested land during and after World War I. This argument was fundamental in convincing Woodrow Wilson and other Allied leaders to support the Czechs in their bid for independence and their claim for specific borders. More importantly these historical arguments were fundamental to the formation of Czech nation-state ideology. With the impending fall of the AustroHungarian Empire the Czechs looked to the past, and specifically to the medieval and early modern Bohemian past, in order to legitimize their claims and assert political power. This chapter explores why these Czech nationalists looked to medieval and early modern history to uncover the arguments employed in 1919 to foster support for Czech statehood as it also delegitimized Habsburg claims. During World War I, Czech nationalists, who attempted to establish home rule under the Habsburg Empire in order to secure language rights began to utilize historic Bohemia to establish an independent Czechoslovakia in the post-war world.

Throughout Bohemia's long tenure within the Austrian Habsburg Empire, few people living in the Bohemian lands considered themselves distinctively "Czech" or had any conception of the boundaries of a Czech nation. Even 
during the last years of the Habsburg rule leading up to World War I, few intellectuals actively sought independence from the Austro-Hungarian Empire; rather, most simply wanted autonomy and language rights under the current monarchy. The outbreak of World War I shifted the status quo as these Czech nationalists, who had previously argued for Czech language rights, used the same justifications based on their distinct language and history in order to establish an independent state. Consequently these intellectuals created a historicized myth of Czechoslovakia, utilizing historical arguments that had been created during the last century in order to establish a direct link between an emerging historic Czech nation to a distant Czech-Bohemian past. ${ }^{4}$

These historical claims, however mythologized, helped establish and legitimize Czechoslovakia, and persist to the present as an integral part of Czech identity. They are therefore essential to understanding the heated border disputes between Czechoslovakia and its neighbors following the end of the Great War. In addition, these historical claims, and resulting myths, are crucial to understanding why the idea of Czech historic rights meshed so well with Wilson's principle of self-determination. This mythology provided the impetus for demanding recognition of land which Czech nationalists claimed as "historic" and traditionally "Czech."

\footnotetext{
4 See Andrea Orzoff, Battle for the Castle: The Myth of Czechoslovakia in Europe, 1914-1948 (New York: Oxford University Press, 2009).
} 
The Czechs used the historic right argument in creating (or "recreating") and legitimizing former Czechoslovakia from 1914 until 1939. Central to understanding this use of history and language is an examination of why the Czechs used medieval history to legitimize their claims and why this argument was effective. Also essential to understanding this process is the role of the Czech "nationalists," and how the situation after World War I required their employment of historical "myth" in order to prove legitimacy and achieve independence. These nationalists are not static and constantly change depending on the domestic and international situation.

Chapter Two explores the question of how Czech and Slovak immigrant groups impacted the relationship between the United States and what would become an independent Czechoslovakia. Though historical myth provided the rhetoric, Czech and Slovak immigrant groups provided the muscle by lobbying the United States government to help their former homelands achieve independence. These connections played no small part in helping endear Wilson to Masaryk and garner support for the independence cause. These and other Czech-formed civil society associations continue, to the present day, to promote good relations between the Czech Republic and the United States. For example, the American Friends of the Czech Republic is the Czech immigrant group in the United States which commissioned and funded (mostly) 
the 2011 Wilson statue in Prague. Coupled with the close personal ties of the Czechoslovakian founding father to America, these immigrant groups played a significant role in the formation of an independent Czechoslovakia.

Finally, Chapter Three analyzes the Wilson Administration and World War I as it unfolds to answer the question of why Wilson chose to support the Czechs and Slovaks in their bid for independence. What changed to make Wilson go from not wanting to break up the Austro-Hungarian Empire to supporting and speaking in support of an independent country of Czechoslovakia? Part of this change in attitude had to do with Wilson's ideas of what the world should look like; one component of his worldview was self-determination.

Wilson's policy of self-determination raised the hopes of the Czechs who, after the outbreak of World War I, began to lobby for independence of the historic lands of Bohemia and Moravia. The reality of the situation, however, proved to be more complicated than Wilson's immediate and blanket approval for Czech independence. Over time, Wilson's attitude toward the dissolution of Austria-Hungary and establishment of Czechoslovakia changed and adapted to events as they evolved during the course of the war and in the course of the Paris Peace Conference. The problems with true self-determination became evident during the Těšín border dispute between Czechoslovakia and Poland as 
well with the Sudeten German question, in which the Allied powers realized the complexities of the multinational East Central European region. 5

These three themes intertwine to create the myth of the creation of Czechoslovakia which can be seen in the Wilson statue in Prague. Therefore, Chapter Four examines the meaning and intent behind the Wilson Statue as a site of memory, and what narrative of the past this monument represents. If the Wilson statue, and other memory sites constructed in the 1920s, served to underscore the close relationship shared by the United States and Czechoslovakia and commemorate Czechoslovakian independence, they also legitimized the power of the new ruling elite. Serving as a political tool to bind two nations together based on shared democratic values and historical circumstances, the monument also illustrates a specific place in time where historical events made the need to create the memory site a political imperative.

Consequently, the memory and legacy of Woodrow Wilson lives on today and can be seen through cooperation between the Czech Republic and the United States. The Czechs truly haven't forgotten about the role the United States played in the creation and independence of their country. Moreover, United States citizens of Czech descent have not forgotten about their ancestral

5 Margaret Macmillan goes into detail in the Těšín border issue between Czechoslovakia and Poland in Peacemakers: The Paris Peace Conference of 1919 and Its Attempt to End War (London: John Murray, 2001). 
homeland. The historic relationship between these two countries plays an important role in their foreign relations to this day. Wilson's principles of selfdetermination continue to impact present political developments and persistent historical memory. Thus, the statue of Wilson perpetuates the myth of the creation of Czechoslovakia and the myth of Wilson in the Czech Republic itself. It also presents the Czech Republic as a distinctly Western state by tying President Wilson and President Masaryk together as dual founding-fathers of Czechoslovakia. This myth is reinforced by both the Czech government and immigrant groups in the United States in the creation and support of this site of memory, the Woodrow Wilson statue in Prague. 


\section{Chapter 1}

\section{Legitimization of Historic Right in the Czech lands}

In order to first understand the importance of Woodrow Wilson to the Czechs, it is crucial to understand Czech national rhetoric at the outbreak of World War I. Then it is possible to understand how the Czechs' political argument of historic right to lands and independence meshed with Wilson's principle of self-determination. As a result, Wilson as champion of Czech independence became integrated into the larger Czech national mythology. As will be evident in subsequent chapters, however, it took Wilson a long time to get on board with the idea of the dissolution of Austria-Hungary and with Czech independence.

Alexei Miller argues in Historical Policy: Eastern Europe Convolutions in the $27^{\text {st }}$ Century, that historic policy, also known as "the broad use of history for political purposes," is a twenty-first century phenomenon. However, there is evidence of the Czechs using this exact type of historical discourse in order to achieve political goals, namely independence from the Austro-Hungarian Empire after the outbreak of World War I. Miller states that it is difficult to "explain the sharp intensification in historical policy in the 2000s." Yet, it is quite simple when you look at the Czech nationalists, who under the Habsburgs 
began to look to medieval history in order to first create a cultural and linguistic identity; and later a political-national identity in order to justify border claims to the Allied governments after using this policy to gain independence. 6

Anthony Smith explains in his article "States and Homelands: the Social and Geopolitical Implications of National Territory," that "to a nationalist, the national territory belongs to a nation by historic right, as a possession of his forefathers for many generations and a repository of sacred memories."7 $\mathrm{He}$ further argues in National Identity that there are certain "fundamental features of national identity" and the first two he lists are "an historic territory, or homeland," and "common myths and historical memories."8 Consequently, these are the two main features of Czech national identity formation in the nineteenth- and twentieth-centuries.

In "Historical Rights: The Evaluation of Nationalists Claims to Sovereignty," Chaim Gans distinguishes between two types of historic rights: chronologically based and value based. Chronologically based historic right states that if an ethnic or religious group has a right to a land if they were the first to inhabit it. Value based historic right explains that a group has a right to particular land if it

\footnotetext{
6 Alexei Miller, "Historical Policy: Eastern European Convolutions in the $21^{\text {st }}$ Century," Russia in Global Affairs 4 (2011), accessed January 2, 2012, http://eng. globalaffairs.ru/number/AChallenge-from-the-Past-15431.

7 Anthony D. Smith, "States and Homelands: the Social and Geopolitical Implications of National Territory," Millennium, Journal of International Studies 10, no. 3 (January 1981), 187-202.

8 Anthony D. Smith, National Identity (Reno: University of Nevada Press, 1991), 14.
} 
is of "primary importance in forming the historical identity." 9 The Czech nationalists actually used both of Gans' types of historic right in order to legitimize their land and independence claims. They argued that Czechs first inhabited the historic lands of Bohemia and also that Czech identity was tied to that land.

\section{Why Medieval and Early Modern History?}

Though the different nationalities that made up the former AustroHungarian Empire wished for greater autonomy within the empire, their desires only came to fruition with independence after World War I and only took place due to Woodrow Wilson's principle of self-determination and western support. Thus Czech nationalists had to underscore a history in which their lands were not ruled by the Habsburgs in order to justify the right to exist as a state. Therefore, looking back to medieval, and to some extent early modern, history became commonplace in Central and Eastern Europe, especially for the newly formed Czechoslovakia.

Bohemia was the Habsburg Empire's wealthiest kingdom due to the rich soil, strategic location, textile industry, mineral industry, and large population.

\footnotetext{
9 Chaim Gans, "The Evaluation of Nationalist Claims to Sovereignty," Political Theory 29, no. 1 (February 2001), 58-60.
} 
Therefore, the Habsburg Monarchy was content to let the Bohemians enjoy greater autonomy within the Empire. 10 This autonomy was all but stripped away by Ferdinand II after the Battle of White Mountain in 1620 when he brought in foreign nobles to replace the rebellious Bohemian ones. Therefore, Bohemian's nobles were replaced by a group that was German, at least in language, and loyal to the Austrians. ${ }^{11}$ These nobles remained fiercely noble to the Austrian Empire after the Counter-Reformation, so they were then angered when, in 1867, the Austrian Empire was reorganized into the Dual Monarchy of AustriaHungary. In other words, Hungary gained equal status with Austria while Bohemia, now loyal in addition to being the most industrialized and richest part of the Empire, did not.

During the late Habsburg Empire, Czech nationals seeking an equal place for the Bohemian lands as Hungarians within the Empire had already begun the process of looking to the past for language and ethnic legitimacy within the Empire; therefore, it became easier to create a national identity for Czechs. In fact, "some people from the region consider the Middle Ages to be the high point in their national historical traditions." 12 This historic Czech myth,

\footnotetext{
10 Charles W. Ingrao, The Habsburg Monarchy, 1618-1815 (New York: Cambridge University Press, 2000), 10-12.

11 Lonnie Johnson, Central Europe: Enemies, Neighbors, Friends (New York: Oxford University Press, 2011 ), 85.

12 Johnson, Central Europe, 26.
} 
already having been created by nineteenth-century nationalists, became the foundation of legitimacy for the new Czech nation.

Czechs also used medieval and early modern history in order to show how foreign subjugation had unlawfully stolen their statehood. Events such as the murder of Jan Hus and the Battle of White Mountain were used to propagate the idea that Czechs had been treated unfairly and deserved the restoration of state independence on their historic lands. ${ }^{13}$

Czech nationalists used three main foundational events or people in order to establish a national myth and link the present with the past. While this is not an exhaustive list, these three show up the most when nationalists later utilized the medieval and early modern past: Jan Hus, Jan Žižka, and the Battle of White Mountain. Jan Hus (1369-1415), a Bohemian priest, is considered a forerunner of the Protestant Reformation about one hundred years prior to Martin Luther. Hus

\footnotetext{
13 On Czech medieval history, see Lisa Wolverton, trans., Cosmas of Prague: The Chronicle of the Czechs (Washington, DC: The Catholic University of America Press, 2009); Hugh LeCaine Agnew, The Czechs and the Lands of the Bohemian Crown (Stanford: Hoover Institution Press, 2004); Hans Brisch and Ivan Volgyes, eds., Czechoslovakia: The Heritage of Ages Past (New York: Columbia University Press, 1979); Johnson, Central Europe; John M. Klassen, Warring Maidens, Captive Wives, and Hussite Queens: Women and Men at War and at Peace in Fifteenth Century Bohemia (New York: Columbia University Press, 1999); Josef Korbel, Twentieth-Century Czechoslovakia: The Meanings of Its History (New York: Columbia University Press, 1977); Jaroslav Panek and Oldrich Tuma Et Alii, A History of the Czech Lands (Prague: Charles University Press, 2009); Derek Sayer, The Coasts of Bohemia: A Czech History (Princeton: Princeton University Press, 1998); Mikulas Teich, ed., Bohemia in History (Cambridge: Cambridge University Press, 1998); C.V. Wedgwood, The Thirty Years War (New York: Methuen \& Co. , 1987); Lisa Wolverton, Hastening Toward Prague: Power and Society in the Medieval Czech Lands (Philadelphia: University of Pennsylvania Press, 2001).
} 
wanted to reform the Church and became popular within Bohemia as a result of his sermons in the Czech language, as opposed to Latin. However, after being accused of heresy and summoned to the Council of Konstanz on the assurances of safety by Emperor Sigismund, he ended up burning at the stake which was later deemed a "national insult" to the Bohemian lands. ${ }^{14}$ Thus began the Hussite revolution as Hus's followers began to resist Church and imperial power, eventually with arms.

Jan Žižka(1360-1424), the one-eyed leader of the Hussite peasant armies, also became a national hero and mythological figure in the Czech national narrative. This occurred mostly because he was able to lead peasants with simple weapons into battle against superior imperial armies and win multiple times. In fact, he forced Emperor Sigismund's army to withdraw from part of Bohemia and then defeated them. ${ }^{15}$ Thus, "heroic images of Czech unity against all were to be recalled in the nineteenth century as a source of national pride." 16

Finally, the Battle of White Mountain (8 November 1620) became a symbol of national tragedy and subjugation for later Czechs. Two years prior, the Thirty Years' War began as a result of tensions between the Catholic Austrian Empire

\footnotetext{
14 Sayer, The Coasts of Bohemia, 37.

15 Hugh Agnew, The Czechs and the Lands of the Bohemian Crown (Stanford: Hoover Institution Press, 2004), 46.

16 Sayer, The Coasts of Bohemia, 39.
} 
and the Protestant Bohemian nobles that culminated in the defenestration of Prague. Ferdinand II defeated the Bohemian nobles, who had rebelled against Ferdinand's counter-reformation policies, and beheaded numerous nobles. Their heads were exhibited on the Charles Bridge for 10 years. This resulted in the victory of the Catholic Counter-Reformation and the effective subjugation of the Bohemian nobility. Ferdinand invited nobles who would be loyal to him to take over land in Bohemia; however, these new nobles came from all over Europe. To complete this conquest, Ferdinand not only made German equal to Czech as an official language of Bohemia, but also placed education under Catholic Jesuit control. Also, as a result of the human devastation of the Thirty Years' War, the region suffered depopulation and as a result, Germans speaking workers began to migrate into the Bohemian lands from the German-speaking states of the Holy Roman Empire. After 1620, the Kingdom of Bohemia which continued to exist within the Austrian Empire was the residue of the much larger Bohemian Kingdom established in the fourteenth century. ${ }^{17}$

As historian Derek Sayer contends, "This modern nation is not so much rooted in that medieval experience as retrospectively reconstructed out of it." 18 Thus, in order to understand the use of history and language during the AustroHungarian Empire and beyond, it is imperative to understand the national

17 Ingrao, The Habsburg Monarchy, 38-39.

18 Sayer, Coasts of Bohemia, 52. 
awakening led by Czech nationalists in the eighteenth and nineteenth centuries which constructed a national myth and identity from this history and coincided with the reemergence of the Czech language.

\section{National Awakening \& Czech Nationalists}

The role of Czech language in establishing the Czechoslovak state cannot be understated. Historians have thoroughly examined how the Czech language, revived during the eighteenth and nineteenth centuries, became a tool used by Czech nationals within the Austro-Hungarian Empire in order to establish linguistic rights. ${ }^{19}$ People living within Bohemia and Moravia prior to the twentieth-century, however, had much more flexible ideas about language, speaking both German and Czech depending upon the social or economic situation. In addition, inhabitants of Bohemia were bilingual depending on vocation or social status. Therefore, Czech nationals had to establish a usable Czech language and expand its vocabulary since it had remained a peasant language despite not being used in the cities for so long.

After the Battle of White Mountain, Habsburg rulers began a long practice of suppressing the local languages and elevating German in the government and education systems in Bohemia as a means to bring the richest area of their

\footnotetext{
19 On Czech language revival, see Hugh LeCaine Agnew, Origins of the Czech National Renascence (Pittsburgh: University of Pittsburgh Press, 1993); and Peter Brock and H Gordon Skilling, eds., The Czech Renascence of the Nineteenth Century (Toronto: University of Toronto Press, 1970).
} 
empire under control. Another goal in implementing this type of reform was to modernize and create a uniform language for administration throughout the Habsburg lands, and also to end repression throughout the Habsburg Empire. However, instead of simply creating an efficient administrative system, these reforms generated regional tensions as affected nobles began to rebel against what they saw as heavy-handed reforms to the status quo. The new reforms specifically targeted non-German-speakers and put them at a disadvantage in what became a forced "Germanization" of the Bohemian lands. Therefore, the Czech language became the focal point of dissent and the preservation of national identity became paramount. The only problem was that Czech was a regional dialect spoken in the Bohemian and Moravian countryside as a result of these language laws.

Maria Theresa and Joseph II, both Habsburg rulers, implemented enlightened reforms which, among other things, stipulated the use of one official language throughout the Empire, German which then turned the language issue into a political issue. ${ }^{20}$ However, they began to promote learning local languages, such as Czech, in schools. ${ }^{21}$ This wasn't a problem for the Czechs because they had to learn German in school already as a result of the reforms made after the Battle of White Mountain. Yet, Germans knew very little, if any,

\footnotetext{
20 Johnson, Central Europe, 115.

21 Ingrao, The Habsburg Monarchy, 218-219.
} 
Czech, which caused German-speaking "Ultra-Germans" to protest on behalf of German language rights thus exacerbating an already growing issue between the Czech-speaking nationalists and the German-speaking nationalists in the Bohemian crownlands. ${ }^{22}$ In response to the rhetoric of these "Ultra-Germans," a new intellectual elite was born in the Bohemian lands which became known as the Czech national "awakeners" who began to "revive" Czech language as well as culture to counter the growing pressure of German language and culture in the Bohemian lands.

National literature and the Czech language had to be revived in order to create some sort of national community. Therefore, in the 1800s, Josef Dobrovsky, Josef Jungmann, Jan Kollar, Pavel Josef Safarik, and Frantisek Palacky all expanded the Czech vocabulary and integrated it into different types of national visions and rhetoric. Ultimately, all these visions, goals, and developments led to the reemergence of a language which could compete with German in Bohemia by the late nineteenth-century. ${ }^{23}$ Masaryk later stated that by placing so much emphasis upon linguistic rebirth, (Czechs) became a

\footnotetext{
22 For a specific instance of these tensions in one region of Bohemia and the German-Czech nationalists issues which followed in Budweiser, see Jeremy King, Budweisers into Czechs and Germans: A Local History of Bohemian Politics, 1848-1948 (Princeton: Princeton University Press, 2002)

23 For more on the development of Czech language and literature and the competing national visions, see David L Cooper, "Competing Languages of Czech Nation-Building: Jan Kollar and the Melodiousness of Czech," Slavic Review 67, no. 2 (2008): 301-320.
} 
'philological' nation." 24 This culminated in the creation of Czech dictionaries, folk songs, cookbooks, almanacs, textbooks, etc.

Eventually, these linguistic struggles took on a deliberately political dimension as Czech national "awakeners" began to compete with Germanspeakers within the Bohemian lands for linguistic dominance. Czech linguistic nationalism also became intertwined with historical arguments thus creating part of the eventual myth of Czechoslovakia. Masaryk argued that as an "awakener," Dobrovsky (1723-1829), a Czech scholar who is credited with the Czech national revival, came from the long tradition of the Czech reformation.

This national awakening escalated in the 1860s with industrialization as Czech-speakers began to move from the countryside to cities for work which challenged the traditional "language borders" separating the Germanspeaking city inhabitants and the Czech-speaking rural inhabitants. ${ }^{25}$ As this movement to the cities greatly increased the number of Czech-speakers in what had previously been predominantly German-speaking urban centers, the balance of power shifted and more Czech nationals began to participate in municipal politics. Therefore, the use of history in Czech politics began with the revival of Czech language and culture.

\footnotetext{
24 Tomáš Masaryk, The Meaning of Czech History, ed. Rene Wellek (Chapel Hill: The University of North Carolina Press, 1974), 19.

25 See Mark Cornwall, "The Struggle on the Czech-German Language Border, 1880-1940," The English Historical Review, 109, no. 433 (1994): 914-951.
} 
Eventually, medieval history also came to be used and altered to fit the national narrative during the national awakening. The Czech nationalists' primary goal was to gain more autonomy within the Austro-Hungarian Empire and establish a federalized state where Prague would have as much autonomy as Vienna and Budapest. However, they had to establish legitimacy in the eyes of Austria in order to attempt to attain the same status as Hungary. The widespread use of history in this region gained momentum under Habsburg rule when Czech nationalists were trying to establish more autonomy and construct a national identity. Thus, nationalists constructed a Czech national identity around the Czech language and the medieval Bohemian past. As Derek Sayer points out in The Coasts of Bohemia: A Czech History, "history itself, in the guise of a recovered memory, was to become a crucial ingredient in the very clear 'consciousness of national identity' that did crystallize among Czechs in the later nineteenth century." 26

What these intellectuals needed to accomplish was to create what Benedict Anderson called "an imagined political community" where its members could feel united even if they had never met.27 However, in Kidnapped Souls: National Indifference and the Battle for Children in the Bohemian Lands, 1900-1948, Tara Zahra contends that studies of nations

\footnotetext{
26 Sayer, The Coasts of Bohemia, 29.

27 Benedict Anderson, Imagined Communities: Reflections on the Origin and Spread of Nationalism (London: Verso, 2006), 5-7.
} 
specifically as imagined communities "may have inadvertently exaggerated the universality and transparency of nationalist loyalties."28 As many scholars have pointed out, national loyalty in the Bohemian lands proved to be a more complicated reality where people living in Bohemia spoke multiple languages and didn't identify with a particular ethnicity. ${ }^{29}$

Several historians focus on the emergence of Czech national identity in the nineteenth century; however, this was not the first time that Czechs had expressed their national identity. In fact, Czech intellectuals, politicians, and nobles had argued for the preservation of their language within the Habsburg Empire after the Thirty Years' War. ${ }^{30}$ Even earlier still, in the $12^{\text {th }}$ century, Cosmas of Prague sought "to define the Czechs as a nation through history, compel them to think about their political culture, and urge reform, justice, and

28 Tara Zahra, Kidnapped Souls: National Indifference and the Battle for Children in the Bohemian Lands, 1900-1948 (Ithaca: Cornell University Press, 2008), 7.

29 For recent scholarship on the contested nature of national loyalties in the Bohemian Lands, see Chad Bryant, Prague in Black: Nazi Rule and Czech Nationalism (Cambridge: Harvard University Press, 2007); Gary Cohen, The Politics of Ethnic Survival: Germans in Prague, 1861-1914 (Princeton: Princeton University Press, 1981); Eagle Glassheim, Noble Nationalists: The Transformation of the Bohemian Aristocracy (Cambridge: Harvard University Press, 2005); Pieter M. Judson, Guardians of the Nation: Activists on the Language Frontiers of Imperial Austria (Cambridge: Harvard University Press, 2006); Pieter M. Judson and Marsha L. Rozenblit, eds., Constructing Nationalities in East Central Europe (New York: Berghahn Books, 2005); King, Budweisers into Czechs and Germans; Cynthia Paces, Prague Panoramas: National Memory and Sacred Space in the Twentieth Century (Pittsburgh: University of Pittsburgh Press, 2009); Nancy M. Wingfield, Flag Wars and Stone Saints: How the Bohemian Lands Became Czech (Cambridge: Harvard University Press, 2007). 30 For an in-depth history of Czech national identity, see Sayer, The Coasts of Bohemia, 29-52. 
responsibility." 31 His work became the foundation stone for the Czech historical myth which emerged during the eighteenth and nineteenth centuries.

In addition to what the Czechs began to construct as their glorious history, events such as The Battle of White Mountain and the burning of Jan Hus at the stake became symbols for national tragedy, martyrdom and subjugation to a foreign power. According to Lonnie Johnson, "The concept of nationalism had to be retrospectively articulated in terms of people's 'ancient' freedoms, which had been violated" or "lost in the past" and "had to be regained or reestablished in the future," even if it was easier to look back to a distinguished and idealized medieval history than the "intervening histories of foreign subjugation, regardless of how long they may have lasted." 32 Thus, Czech nationals who wanted either autonomy within or freedom from the AustroHungarian Empire actively linked the past to the present. For example, in a speech in 1910, Masaryk linked the Czech national revival of the eighteenth century to the Hussite reformation in order to provide a historical continuity basis for the current political struggle against the Austro-Hungarian Empire. This historical narrative, however, did not leave room for any other victims of history within the Bohemian lands; it also created the necessary perpetrator or villain for

\footnotetext{
31 Wolverton, Cosmas, 3. While some argue that Cosmas' account is biased, this is the first attempt to chronicle the history of the Czechs and evaluate power in medieval society, which he began around 1120, and it began a literary tradition for the Bohemian lands.

32 Johnson, Central Europe, 26-8.
} 
the nation to rally against, the Germans of Bohemia and Moravia.

The power behind this cultural production of history by Masaryk and others gains credibility as it is based in facts. The Habsburgs, specifically Ferdinand II, completely subordinated and then "Germanized" the nobility of the Kingdom of Bohemia during the Counter-Reformation in such a way as to render it incapable of resistance in the future. The culminating battle in this conflict, the Battle of White Mountain, is arguably "a crucial concept in the raising of Czech national consciousness in the nineteenth century;" however, "it continued to have a nationalist connotation in Czech politics long into the twentieth century." 33 White Mountain can be viewed as the beginning of German oppression which culminated in the expulsion of Germans after World War II. Conversely, there was a history of coexistence that Czechs and Germans had before the rise of modern nationalism. Germans were invited and welcomed into Bohemia to work prior to this time period and were seen as meaningful to society and culture. Either way, Battle of White Mountain was a turning point in Czech-German relations, part of the myth of Czechoslovakia, which culminated in the eventual expulsion of Germans from Bohemian lands.

By the late nineteenth-century, Czech and German nationalists began to use language as a measure of nationality. In the Bohemian lands, the only real

33 Teich, Bohemia, 16. 
or tangible difference between Germans and Czechs was language. Thus language became the battleground for nationality politics. Czech and German nationalists alike were faced with a fundamental problem. A vast majority of individuals living within the Bohemian lands remained indifferent to nationalism, nationalist appeals, and politics. Attempts at "conversion" on the basis of language was largely met with indifference and disinterest from both German and Czech speakers. Zahra argues that this indifference to nationalism was ultimately the driving force behind escalating nationalist tensions and battles over nationality. ${ }^{34}$ Moreover, families viewed bilingualism as a benefit and made sure their children knew both Czech and German. Thus, the battle over these "hermaphrodites," or bilingual children, ensued, each side trying to gain linguistic converts. ${ }^{35}$ While this was largely a Czech versus German problem, it created a political climate through its rhetoric which was toxic to anyone categorized as "other" or outside the nationality. It also propagated the idea of Bohemian lands specifically for Czech speakers which meant no more tolerance for bilingualism and plurality of ethnic groups.

The Czech nationalists also began to frame their argument for greater autonomy within the Austro-Hungarian Empire's existing framework on the basis

\footnotetext{
34 Zahra, Kidnapped Souls, 4.

35 See, Zahra, Kidnapped Souls.
} 
of historic right. The principle of historical right "tried to prove that the Czech state had never ceased to exist legally;" thus, "constitutional independence... had never been legally interrupted. "36 It became an avenue through which Czech nationalists could attempt to reassert a number of constitutional rights of the previous Bohemian Kingdom. Originally among the national awakeners, no vision of an independent state existed as these nationalists mainly wanted greater autonomy within the empire, much like that enjoyed by Hungary after 1862. Nationalists began to call for a tri-monarchy together with Austria and Hungary on the basis of the historic right of the Bohemian crown. In addition, the use of historic right of the Bohemian crown "did not correspond to ethnographic facts, but it was applicable as an effective political oversimplification."37 Thus this principle sought to establish a political and territorial entity as opposed to a national one within the Bohemian lands which is important because then the economically rich and developed territory would not have to be divided into Czech and German parts.

Another concept which was developed during the national revival and progressively evolved during the nineteenth century was that of Czechs' "democratic exceptionalism." Czech nationalists in the late nineteenth century

\footnotetext{
36 Jaroslav Krejci and Pavel Machonin, Czechoslovakia 1918-1992, A Laboratory for Social Change (New York, 1996), 104.

37 D Perman, The Shaping of the Czechoslovak State: Diplomatic History of the Boundaries of Czechoslovakia, 1914-1920 (Netherlands: E.J. Brill, 1962), 11.
} 
created this idea of Czech affinity for democracy which later played a role in legitimizing the Czechoslovak nation-state and acquiring its requested borders. One way in which history had a positive effect on future events is in democratic development. As Lonnie Johnson argues in Central Europe, the "destruction of Bohemia's feudal nation in the seventeenth century" after the Battle of White Mountain "contributed to the evolution of a more modern and democratic Czech political culture in the long run." 38 Recently, scholars of Czech history have been critical of the "democracy" of Czechoslovakia, calling it a failure and a farce. However, Zahra argues that it is necessary to understand the Czech conception of democracy and not strictly measure it against an established Western model.

\section{Creation of National Identities \& Minorities - Late Austrian Empire}

In the late nineteenth century the Habsburg Empire, under the strain of a large, inefficient bureaucracy, enacted reforms designed to create greater efficiency throughout the Empire. Thus, the official language of the government became German which subsequently created a backlash in the Bohemian lands among the Czech nationalists who believed this to be an infringement on their historic right. It also began the escalation of the Czech versus German conflict on the basis of language. Conversely, when Czech became a

\footnotetext{
38 Johnson, Central Europe, 88.
} 
language requirement in schools, German nationalists began accusing German-speaking officials of "forgetting their completely German origins" for not opposing this decision. ${ }^{39}$

As discussed before, this led to competition over "amphibians" and a gradual radicalization of political positions when faced with an indifferent population. However, some extremist, or "Germanomaniac," German-speaking imperial authorities created a discourse which exacerbated the situation and caused some Czech nationalists to change their goal from autonomy within the Empire to independence from the Empire. As a result of the language laws, the Austro-Hungarian administration ended a situation where being "German" meant a privileged place among the elites and a part of the government. On the contrary, it created a space for non-German nationalists outside the government which hadn't existed before. Therefore, instead of creating a singular "German" state identity, the Austro-Hungarian Empire exacerbated existing divisions that helped to bring about its own demise.

Even among Czechs, however, there did not emerge any sort of popular consensus on what it meant to be Czech or have a Czech identity, which explains the multitude of figures and symbols associated with the Bohemian lands. One has to look no further than the myriad of monuments and festivals

39 King, Budweisers into Czechs and Germans, 2. 
which commemorate a variety of mythologized figures associated with different visions of national and religious identity. 40 Therefore, even Czech identity was fluid and contested on a variety of different levels as well.

Jews, another minority within the Bohemian lands, did not develop their own national identity within Bohemia in response to this categorization of "other." Instead they "assimilated into dominant national cultures." $" 41$ Frequently Jews became "Germanized" and took on a German national identity in addition to the language. ${ }^{42}$ One of the main reasons for this is due to the fact that the majority of Jews lived in the cities in the Bohemian lands which were, until the Industrial Revolution, predominantly German. Unfortunately this led to resentment among Czech nationalists and a conflation of Jews with Germans which had disastrous effects later on.

The outbreak of World War I completely changed the rhetoric of Czech nationalists as will be explored in the next two chapters. The political elites, who were in exile, including the future president, Masaryk, made the decision to attempt to establish Czechoslovak independence. However, he needed to

\footnotetext{
40 For more on the issues surrounding Czech attempts to manipulate public space to create a single vision of the nation-state among Czechs, see Paces, Prague Panoramas; for more on the issues between Czech and German attempts to mark their public space for national selfdefinition, see Wingfield, Flag Wars.

41 Johnson, Central Europe, 136.

42 On this phenomenon in Germany, see Deborah Hertz, How Jews Became Germans: The History of Conversion and Assimilation (New Haven: Yale University Press, 2007).
} 
establish some sort of legitimacy for the new state's right to exist. Thus, he borrowed on nationalist ideas of historic right in order to present his vision of Czechoslovakia to the Allied powers. In a speech in 1918, remarking on the significance of the Czechoslovak state, he contended:

The Czechs will not be satisfied with the concession of national autonomy within an Austrian federation. They have a historical right to the independence of the Czech lands (Bohemia, Moravia and Silesia); they insist on their right to the independence of the State created by them. In addition to that, they have a historical and natural right to union with Slovakia, so brutally oppressed by the Magyars. ${ }^{43}$

Therefore, Masaryk applied the argument for historic right to Bohemia, Moravia, and Silesia. He also includes Slovakia in this new state for strategic purposes. However, since Slovakia and the Bohemian lands had much different historical pasts, this argument also had to be made on the basis of ethnic lines. Nonetheless, the argument for the inclusion of Slovakia manipulated history for political expedience. As Edvard Beneš, Masaryk's counterpart in exile in Paris argued:

The term Czecho-Slovaks, or simply the Czechs, includes two branches of the same nation: Czechs and Slovaks" which "have the same

43Jan and Zdenka Munzer, eds., We Were and We Shall Be: The Czechoslovak Spirit Through the Centuries (New York: Frederick Ungar, 1941). 
civilization, the same language and history. ${ }^{44}$

Not only does this statement exemplify the manipulation of history, but it also shows a manipulation of ethnicity as he states that all Czechs and Slovaks should simply be called Czechs.

Ironically, the Czech politicians argued against drawing any ethnic lines through the Bohemian lands on the rationale that the cities and districts were so ethnically intermixed that any territorial division of ethnicities would create a large Czech minority in German lands, which was unacceptable. The Czechs, however, wished to retain the German, Polish, and Hungarian minorities within the new Czechoslovak state with certain minority rights guarantees such as schools in minority languages as well as representation in the new government. 45 There was also the hope that Czechs and Germans could live in peace after a decisive defeat of Germany in the war. Even when these German parts of Czechoslovakia began to protest in order to remain a province of Austria, the Czechs refused to give in because "the principle of the integrity of the historic Bohemian-Moravian frontiers was not negotiable." 46

However, the Czech nationalists made one mistake which cost them their independence to Nazi Germany in 1938-1939. As Margaret Moore explains in

\footnotetext{
44 Edvard Beneš, Bohemia's Case for Independence (London: G. Allen \& Unwin Ltd., 1917), 1. 45 Margaret Macmillan, Peacemakers, 248.

46 Joseph Rothschild, East Central Europe between the Two World Wars (Seattle: University of Washington Press, 1983), 79.
} 
The Ethics of Nationalism, "appealing to historical links can legitimize claims to vast areas and many different irredentist claims." 47 Another problem with historical right which Moore discusses is that the adjudication of competing claims to a disputed territory depends "on where in history one starts, and whose history one accepts." 48 This is unfortunately a problem which is still contested today in numerous areas of the world where national groups or states claim a particular multiethnic territory. This problem is incredibly difficult to solve when the argument of historic right was confronted by counter-claims of an ethnic majority, such as in the Czech case of the Sudetenland. Unfortunately, this case ultimately ended in the forced expulsion of the Germans over contested historical rights after World War II which created a largely homogenous Czechoslovakia.

Thus it is obvious that the argument of historic right played a large part in the Czech's national awakening, but also in the quest for independence. While this historic right argument is problematic, it still became part of the national myth of the Czech people and eventually the state of Czechoslovakia. It also profoundly affected the immigrants in America who emigrated from Bohemia whether for economic or political reasons. These immigrants who worked tirelessly for the independence of the Czechs and Slovaks are the subject of the

\footnotetext{
47 Margaret Moore, The Ethics of Nationalism (Oxford: Oxford University Press, 2001), 190.

48 Moore, Nationalism, 190.
} 
next chapter. 


\section{Chapter 2}

\section{Influence of Immigrant Groups and Personal Connections}

In "What Woodrow Wilson and America Meant to Czechoslovakia," Herbert Adolphus Miller explains that before United States entry into the First World War, Americans were largely ignorant of Bohemia and the Czechs. He further explains that there were only six books in English about Bohemia and the Czechs up to 1918.49 However, there existed large immigrant communities of Czechs and Slovaks all over the United States which, once united, caused the rest of America to take notice. Yet the relationship between the United States and Czech people actually began in 1848. The Revolution of 1848 not only "helped Americans discover East Central Europe," but it also "prompted the first large Czech and eventual Slovak migrations to America." 50

An important factor of American support for Czecho-Slovak independence during World War I began after Tomáš Masaryk became a well known public figure. In order to fully understand the legacy of Wilson and his impact on the memory of Czechs for the creation of Czechoslovakia, it is necessary to understand the work done by Tomáš Masaryk and Czech-

\footnotetext{
49 Herbert Adolphus Miller, "What Woodrow Wilson and America Meant to Czechoslovakia" in Czechoslovakia, ed. Robert J Kerner (Berkeley: University of California Press, 1949), 71-72.

50 Elizabeth Anne Murphy, "Initiative Help: United States-Czechoslovak Relations from Versailles to Munich" (PhD Diss., Cornell University, 1999), 2.
} 
American civil society groups to convince Wilson to support an independent Czechoslovak state.

Tomáš Masaryk began his career as a professor of philosophy at the University of Prague. His wife, Charlotte Garrigue, was born in Brooklyn and they were married in New York. He even took her last name and became Tomáš Garrigue Masaryk. Later, after visiting the United States again in 1907, he became convinced that "Czech-Americans were an important part of the Czech nation and that America could be a source of inspiration for Czech political life."51 Masaryk was also influential and well known with Entente circles as an informant.52 Masaryk had worked previously in the Austrian Reichsrat (Parliament) as part of the Young Czech movement which was based on the belief that participating in the government would increase Czech representation as well as Czech political influence. Later he served in the Reichsrat again as the founding member of the Realist Party. As a result he was in the perfect position to supply the Entente powers and their allies with AustroHungarian intelligence as well as provide useful propaganda which the Entente

\footnotetext{
51 George Kovtun, Masark \& America: Testimony of a Relationship (Washington, D. C.: Library of Congress, 1988), ix.

52 For more information on Masaryk's time as an informant, see R.W. Seton-Watson, Masaryk in England (New York: The Macmillan Company, 1943)
} 
used to garner support at home for the war. ${ }^{53}$

Masaryk's personal connections also proved immensely useful. Masaryk was friends with wealthy American businessman Charles Crane who had important government connections, influence, and money, and valued him as an "admirable auxiliary for he knew nearly everybody whom Masaryk wanted to meet and was close to President Wilson." 54 Crane's friendship proved even more profitable when, in 1915, Masaryk asked Crane for monetary assistance as the Czechs worked toward independence from Austria-Hungary. After Czech independence his son, Richard Crane, became the first United States ambassador to the newly formed Czechoslovakia. The connection between these two families doesn't end there; in 1924, Masaryk's son Jan Masaryk married Charles Crane's daughter, Frances.

\section{Immigrant Influence on United States Policy}

The earliest Czech immigrants to America came after 1620; however, there were very few at first. Most Czech immigrants settled in Chicago, New York, St. Louis, Philadelphia, Pittsburgh, Texas Pennsylvania, lowa, Minnesota,

\footnotetext{
53 For more about Masaryk's personal life and history before his role in Czechoslovak independence, see Kovtun, Masaryk \& America,

54 Tomáš Masaryk, Making of a State: Memories and Observations, 1914-1918 (New York:

Frederick A Stokes Co., 1927), 221.
} 
Nebraska Oregon, and California.55 They first formed sokols, gymnasiums, and began newspapers; however, when World War I broke out, more political groups emerged. One of the unique advantages of a democracy is the ability of groups of people to come together for a common cause. Often called civil society, these independent networks of voluntary associations or groups can simply hold meetings, or they can attempt to affect changes in policy or their government. In Joseph Grady's work, The Immigrants' Influence on Wilson's Peace Policies, he contends that part of President Wilson's political philosophy was that "the people should rule" and thus he "welcomed pressure from the people."56 Therefore, ambitious immigrant groups felt that it would be fruitful if they lobbied the U.S. president and government on behalf of their mother countries.

According to Nancy G. Ford in Americans All!: Foreign Born Soldiers in World War I, "ethnic leaders saw their peoples' participation in the fighting as a way of demonstrating loyalty to their adopted country and bringing liberation and independence to their homeland." 57 This was exactly the philosophy of the Czech and Slovak immigrants in forming these groups and working for their 55 For more on early Czech immigration, see Joseph Chada, The Czechs in the United States (Washington D.C.: SVU Press, 1981).

56 Joseph P. O'Grady, "Introduction," in The Immigrants' Influence on Wilson's Peace Policies, ed. Joseph P. O'Grady (The University of Kentucky Press, 1967), 4.

57 Nancy G. Ford, Americans All!: Foreign-Born Soldiers in World War I (Bryan-College Station: Texas A\&M University Press, 2001), 28. 
homelands' independence. As Otakar Odlozilik points out, "the Czechs (in America) engaged in little political activity before 1914," thus a majority of these political groups were formed as a response to the war and the prospect of Czecho-Slovak independence. 58 United States entry into the war caused these immigrants to join the United States military and fight against who they viewed as Bohemia's true oppressors, the Austro-Hungarian Empire. To a large extent, this proved to be a useful venture and helped bring about Czech Independence. However, volunteering to serve in the United States army was not the most important factor but part of a larger phenomenon of émigré political influence on emerging Czech-American relations. It's also worth mentioning that a majority of the immigrants who joined the United States military did so in order to prove their loyalty to their new country and its allies since technically they were fighting against the state from which they came, the Austro-Hungarian Empire.59

These Czech civil society groups in America adopted the expressed goal of bringing about Czech independence after the outbreak of World War 1.60 When the war broke out these groups formed to offer support to their fellow

\footnotetext{
58 Otakar Odlozilik, "The Czechs," in The Immigrants' Influence on Wilson's Peace Policies, ed. Joseph P. O'Grady (The University of Kentucky Press, 1967), 207.

59 See Joan McGuire Mohr, The Czech and Slovak Legion in Siberia, 1917-1922 (North Carolina: McFarland \& Company, 2012).

60 Betty Unterberger, The United States, Revolutionary Russia, and the Rise of Czechoslovakia (College Station: Texas A\&M University Press, 2002), 24-25.
} 
Slavs, the Serbs, or to provide relief in the form of contributions to the Serbian Red Cross. There also emerged a number of Slovak groups which had the same purposes as the Czech. The first large Czech group which called for independence from the Austro-Hungarian Empire formed the Bohemian National Alliance in Cleveland in March 1915; however, its headquarters were located in Chicago. These two cities had the largest concentration of Czechs in America, so it made sense that this is where the movement began.

The Czech and Slovak immigrant groups began to work together for the larger goal of independence of Slavic nations in Austro-Hungarian held territories. The Cleveland Pact, between the Slovak League of America and the Bohemian National Alliance, in October 1915 stated the goal of these two groups were for Czecho-Slovak independence.61 Other groups existed which also promoted Czech and/or Slovak interests in America such as the National Alliance of Catholic Czechs, the Czech National Federation, the First Slovak Evangelical League, the National Alliance of Bohemian Catholics, to name a few.

These groups also created organizations such as the Czech-Slav Press Bureau with the expressed goal of garnering support for Czecho-Slovak independence as well as putting out propaganda about the evils of the Austro-

${ }^{61}$ Murphy, "Initiative Help," 32-33. 
Hungarian Empire, and the Czechoslovak Relief Council which later became known as the Czechoslovak Red Cross. There were also newspapers such as the Bohemian Review, which kept Czechs and Slovaks informed of critical events of the war as well as independence efforts in America and abroad. In addition, Czech groups in other countries became active in the independence movement as well.62 It is important to mention that Czech and Slovak émigré and exile communities in London and Paris also proved influential in lobbying Western governments for Czecho-Slovak independence.63

Perhaps the most influential of all the Czech-American émigré groups was the Czechoslovak National Council of America (CNCA), formed in 1917. It consisted of three groups, the Bohemian National Alliance, the Slovak League of America, and the Czech Catholics. The CNCA lobbied Washington for Czech and Slovak independence. Czech- and Slovak-Americans even donated money to the Czecho-Slovak independence cause.

What raised the status of the CNCA was the establishment of invaluable contacts with Senator William S. Kenyon of lowa, Representative Adolph J. Sabath of Chicago, Secretary of State Robert Lansing, diplomat and presidential

\footnotetext{
62 There were Czech groups which formed to lobby other Allied governments such as the Committee of the Czech Colony and Paris Volunteers in Paris; the Bohemian Committee in London; the Council of Russian Czechs in Russia.

63 Pierre Crabitès, "The National Council," in Beneš, Statesman of Central Europe (New York: Coward-McCann Inc, 1936), 52-65.
} 
advisor Colonel Edward House, and State Department chief of the Near Eastern

Division Dr. Albert Putney. When Masaryk arrived in the United States in 1918, he benefited greatly from all the networking already done in this area by the CNCA. The CNCA lobbied these important people on behalf of an independent Czecho-Slovak state and, while it is unclear how much these contacts helped in the independence effort, it is clear that they helped United States decision-makers become aware of and familiar with the issue at hand.

\section{Masaryk and Independence}

In May of 1918, Masaryk travelled to Chicago in order to get American support, and Charles Pergler was appointed from the Bohemian Alliance to become Masaryk's secretary. Pergler wrote about this time later in his book America in the Struggle for Czechoslovak Independence. One of the most influential meetings of the CNCA began that same month when Masaryk met with its members and together they drafted the Pittsburgh Agreement. This document became the basis for Czecho-Slovak independence and the Czecho-Slovak Declaration of Independence which occurred later in October.

Finally on June 19th, 1918, Masaryk met with Wilson. Much of the conversation centered on whether or not the Czech Legion in Siberia could be used against the Russian Bolsheviks. Thus, another important factor in the Western support of the Czechoslovak position was the role of the Czech military 
forces. Czech forces, unlike those of other Austrian Empire nationalities, were militarily effective and well organized so that the "bargaining position of the Czechs was improved by their military contribution to the Allies." 64 Other Slavic soldiers in the armies of the Central Powers refused to fight the Czechs and would actually desert their regiments when faced with Czech soldiers; therefore, the Allies began to use the Czechs toward the end of the war. However, the key influential factor proved to be the Czech Legions, which had been awaiting evacuation from Siberia but remained available in case of the necessity of Allied intervention in the Russian civil war. In addition, they carried out missions for the Allies such as holding the Trans-Siberian Railway. Beneš viewed the Legions in Siberia as "an asset which could be used to secure definite recognition of Czechoslovak political and territorial aspirations."65 Therefore, the potential use of Czech military forces proved invaluable in attaining Allied political support for a Czechoslovak state.66

Interestingly, this army recognized the Czecho-Slovak CNCA in the United

\footnotetext{
64 Perman, Czechoslovak State, 33.

65 Perman, Czechoslovak State, 35.

66 For more on this subject, see Christopher Lasch, "American Intervention in Siberia: A Reinterpretation," Political Science Quarterly 77, no. 2 (June 1962); Josef Kalvoda, "Masaryk in America in 1918," Jahrbücher für Geschichte Osteuropas, Neue Folge, 27. 1, 85-99; Gustav Bečvár̆, The Lost Legion (London: Standley Paul, 1939); John Bradley, The Czechoslovak Legion in Russia, 1914-1920 (New York: Columbia University Press, 1991); Victor M. Fic, The Collapse of American Policy in Russia and Siberia, 1918 (Boulder, CO: East European Monographs, 1995); Edwin Hoyt, The Army without a Country (New York: Macmillan, 1967); Betty Unterberger, America's Siberian Expedition, 1918-1920 (Durham, NC: Duke University Press, 1956); Mohr, The Czech and Slovak Legion in Siberia.
} 
States as its political and military authority when acting in the region. 67 However, Masaryk was opposed to the idea of using the Czech Legions against the Bolsheviks and encouraged Wilson and Lansing to utilize Japanese intervention instead. Masaryk did not know what Wilson hoped to accomplish with only 50,000 or 100,000 troops. 68 Yet, these troops succeeded in controlling parts of the Trans-Siberian Railway. While Masaryk preferred a Japanese option, Wilson still favored using the Czech troops.69

The United States government believed that the announcement of support for the Czechs in May of 1918 would encourage the Czechs in America to support the United States in World War 1.70 However, the Czechs already actively supported the Allied war effort, mostly as a means to end imperial rule of their homeland. As a result of all of these activities, on October 18 th, 1918, Masaryk released the Declaration of Czechoslovak independence and one month later he was elected the first President of Czechoslovakia. Ironically, Masaryk became President of Czechoslovakia while still in Washington D.C. The Czechoslovak Declaration of Independence, written in the United States in

\footnotetext{
67 Odlozilik, "The Czechs," 216.

68 Kalvoda, "Masaryk in America in 1918," 91.

69 See Unterberger, The United States, Revolutionary Russia, and the Rise of Czechoslovakia; and Mohr, The Czech and Slovak Legion in Siberia.

70 United States Department of State, Papers Relating to the Foreign Relations of the United States, 1918, Supplement 1, The World War, vol. 1 (U.S. Government Printing Office, 1918): 808809, http://digital. library, wisc. edu/1711.dl/FRUS. FRUS1918Supp01v01.
} 
English, even had Woodrow Wilson's name in it.

We accept the democratic principles of America and France; we accept the American principles as laid down by President Wilson: the principles of liberated mankind - of the actual equality of nations - and of governments deriving all their just powers from the consent of the governed. ${ }^{71}$

Aviel Roshwald states that Masaryk is "the most striking example of how war-time exiles in the Allied countries could propel a hitherto respected but relatively powerless figure into the seat of power."72 Masaryk was a well known educator, intellectual, and politician in Bohemia before the war; however, no one would have thought at the time he would be the first president or leader of an independent Czechoslovakia. His work with the Allied leaders, especially Wilson, and with immigrant and émigré groups in the West, especially those in the United States, gained him the political fame which awarded him this distinguished position.

In the national myth of the creation of Czechoslovakia, Masaryk is given credit for "converting Wilson to an anti-Austrian policy."73 Masaryk himself later contended that he and Czechs abroad were responsible for Wilson's support of

\footnotetext{
71 Kovtun, Masaryk \& America, 51.

${ }^{72}$ Aviel Roshwald, Ethnic Nationalism and the Fall of Empire: Central Europe, Russia, and the Middle East (New York: Routledge, 201 1), 129.

73 Victor S. Mamatey, "The Establishment of the Republic," in A History of the Czechoslovak Republic, ed. Victor S. Mamtey and Radomír Luža (Princeton: Princeton University Press, 1973), 21.
} 
Czech independence.

Thus I was able, step by step, to persuade the President and Mr. Lansing to accept (Czech independence). But this was by no means the result of my personal influence alone. The work and propaganda of our people won us public goodwill - and Austria-Hungary lost it. ${ }^{74}$

It is important to note, as several historians have pointed out, Masaryk didn't singlehandedly persuade Wilson to accept Czechoslovak independence. There were other factors such as the Czech Legion in Siberia, which will be discussed in Chapter Three. However, this became part of the national myth and political discourse on Czech independence. Thus, this idea of Wilson as defender of the Czechs is also based on the myth that he was won over to their worthy cause by Masaryk, which became the basis for the idea of Masaryk and Wilson as twin champions of Czech independence.

This view of Masaryk and Wilson as co-champions of Czech independence was accepted by the United States government as well. This is evident when looking at the 1968 document, Background Materials Designed for Use in the Preparation of Statements and Speeches Commemorating Czechoslovak Independence Day (October 23rd) and the Bithday of Czech President Tomáš Masaryk (March 7), found in the Library of Congress:

74 Masaryk, Making of a State, 274. 
In the summer of 1918, Masaryk conferred with President Wilson and effectively laid the groundwork for full American support for the Czechoslovak cause of national independence. On July 8 , Beneš sent a letter to Prague in which he elaborated on the extent of American support. 'Masaryk is in America,' he wrote. 'He has spoken several times with Wilson, and informs me that our cause has been won so completely that Wilson and the American government have promised not to make any fundamental decisions on Austro-Hungarian affairs without us or without our approval. 75

Therefore, it is evident that this myth of Wilson and Masaryk is actually proliferated by both the Czech and American governments beyond simply the creation of Czechoslovakia.

75 Library of Congress, Background Materials Designed for Use in the Preparation of Statements and Speeches Commemorating Czechoslovak Independence Day (October 23rd) and the Birthday of Czech President Tomáš Masaryk (March 7) (October 4, 1968), LRS-4. 


\section{Chapter 3}

\section{Self-Determination: Wilson's Policies Toward the Czechs During and After World War I}

It is important to understand that the principle of self-determination was one part of Wilson's broader foreign policy worldview. According to Gordon Levin in Woodrow Wilson and World Politics," Wilson's goal was to "create an international civil society" by "Americanizing" the rest of the world thus "creating a world society under law, to be preserved through the moral and material strength of the international social contract embodied in the League of Nations."76 Therefore, Wilson wanted to create a democratic, peaceful, stable world. He believed that in order to create this new stable democratic world, there must be a free flow of ideas and commerce across national boundaries. These ideas culminated in the League of Nations in which Wilson as the "fulfillment of his long effort to use America's moral and material power to move the world from a warlike state of nature to an orderly global society governed by liberal norms."77 The final piece to Wilson's worldview was self-determination.

In elaborating the principle of self-determination of nations Woodrow

\footnotetext{
76 Norman Gordon Levin, Woodrow Wilson and World Politics: America's Response to War and Revolution, (New York: Oxford University Press, 1968), 4.

77 Levin, Woodrow Wilson and World Politics, 9.
} 
Wilson stated, "Every people has a right to choose the sovereignty under which they shall live."78 Wilson came from an International Relations school of thought which today is called idealism and is known for looking at the world the way it ought to be according to Western liberal ideas as well as emphasizing cooperation among like-minded nations. While his contemporaries were skeptical of Wilson, the application of his idealism to foreign policy today has caused some scholars and practitioners to claim that he was ahead of his time. Henry Kissinger even stated, "Wilsonianism has survived while history has bypassed the reservation of his contemporaries."79

Ben Rosamond states that the idealist emphasizes the "perfectibility of humanity and the virtues of collective security, postnational systems for peace and the advocacy of international organisations." 80 As an idealist, Wilson's principle of self-determination conforms to contemporary liberal internationalism theory which focuses on morality and cooperation in international politics. One could even argue that the Velvet Divorce of Czechoslovakia into the Czech Republic and Slovakia was a direct result of the legacy of Woodrow Wilson and his policies of self-determination. However, this is a topic for another work. Nevertheless, it is from this school of thought that we can understand Wilson's

\footnotetext{
78 Woodrow Wilson, The Messages and Papers of Woodrow Wilson, ed. Albert Shaw, vol. 1 (New York: The Review of Review Corporation, 1924), 247

79 Henry Kissinger, Diplomacy (New York: Simon \& Schuster, 1994), 30.

80 Ben Rosamond, Theories of European Integration (Palgrave Macmillan: Hampshire, 2000).
} 
moral, idealistic vision of American foreign relations as it took shape during World War I.

Wilson's ideas didn't occur spontaneously and independently. As Betty Miller Unterberger explains, we must understand self-determination in the American context as it developed over time. ${ }^{81}$ Therefore it is imperative to briefly examine self-determination as expressed in the United States experience. The colonies in North America began as an expression of self-determination. Europeans who wanted to get away from oppressive rulers came to American shores in order to have the right to "determine their own political destiny." 82 The American Revolution occurred as a continuation of this belief in the right of a people to govern themselves. Essentially, America was founded on the principle of self-determination, although it wasn't called that explicitly at the time. Thomas Jefferson stated it best when he said, "We surely cannot deny to any nation that right whereon our own government is founded, that everyone may govern itself according to whatever form it pleases and change those forms at its own will." 83

\footnotetext{
81 Betty Miller Unterberger, "The United States and National Self-Determination: A Wilsonian Perspective," Presidential Studies Quarterly, 26, no. 4 (Fall 1996): 926.

82 Unterberger, "Self-Determination," 926.

83 Thomas Jefferson as quoted in: Unterberger, "Self Determination," 926.
} 
The idea of self-determination in America changed as the United States government began to get involved in more foreign entanglements. Therefore, President Millard Fillmore proclaimed that if America truly believed in selfdetermination, it should stay out of other nation's affairs. The American Civil War further cemented the government's non-interventionist policies as the Union rejected any foreign intervention in the conflict; however, as the Confederacy claimed the principle of self-determination in its rebellion it became a problematic stance. Self-determination of nations became an idea that America expressed, but not as a foreign policy goal that would cause the government to act. 84

\section{Wilson and Czecho-Slovak Self-Determination}

Wilson didn't feel that the tenets of self-determination expressed in the Declaration of Independence were "merely a statement of political ideals but also a program for action." Wilson believed that self-determination "meant

\footnotetext{
84 For more on self-determination after Wilson see Brad Simpson, "The United States and the Curious History of Self-Determination," Diplomatic History 36 no4 (September 2012), 675-694; Tony Smith, America's Mission: The United States and the Worldwide Struggle for Democracy in the Twentieth Century (Princeton NJ: Princeton University Press, 2012); Erez Manela, The Wilsonian Moment: Self-Determination and the International Origins of Anticolonial Nationalism (Oxford, 2009); Rupert Emerson, Self-Determination Revisited in the Era of Decolonization (Cambridge, MA, 1964); Tomáš Frank, "The Right to Self-Determination in Very Small Places," NYU Journal of International Law and Politics 8 (1975), 379-384; V.P. Franklin, Black Self-Determination: A Cultural History of the Faith of the Fathers (Westport, Ct, 1985).
} 
government by consent of the governed - a moral necessity." 85 Yet, Wilson didn't define the concept or its application; he also came to realize the complications in applying this idea to foreign policy during the postwar peace conferences. Even for contemporaries, Wilson's idea of self determination proved difficult to define: "When the President talks about 'self-determination', what has he in mind? Does he mean a race, a territorial area, or a community? Without a definite unit which is practical, application of this principle is dangerous to peace and stability." 86

Allen Lynch also argues that Wilson didn't have much knowledge of East Central Europe when he made speeches about self-determination and positioned it among his Fourteen Points, which he came to realize at the Paris Peace Conference. ${ }^{87}$ Later, Wilson had to make good on certain promises that otherwise wouldn't have been made if not for the war. First, however, he had to come to the decision to dissolve Austria-Hungary, a decision that didn't occur as early or have as much support as Czech nationalists previously believed.

It is well documented that Wilson did not want to dissolve the AustroHungarian Empire, and he worked secretly with the Habsburgs in order to try to bring them to the peace table in order to isolate Germany. Despite the work of

\footnotetext{
85 Unterberger, The United States, Revolutionary Russia, and the Rise of Czechoslovakia, 90-91.

86 Robert Lansing, "Self-Determination," Saturday Evening Post (April 9th, 1921), 7.

87 Allen Lynch, "Woodrow Wilson and the Principle of 'National Self-Determination': A

Reconsideration," Review of International Studies 28 (2002), 419
} 
the immigrant groups in the United States as well as Masaryk, Wilson wasn' $\dagger$ ready to commit to the dissolution of Austria-Hungary. Only when these secret talks fell through in the fall of 1918 did Wilson begin to seriously consider openly supporting the Czechs and Slovaks in their independence aims.

Although Wilson still wasn't set on Austro-Hungarian dissolution, as soon as he stated "that every people has the right to choose the sovereignty under which they shall live," he became the unwitting champion of the Czechs and Slovaks who argued for independence.88 On January 10th, 1917, the Allied powers stated their war goals, which included "the liberation of Italians, of Slavs, of Roumanians and of Czecho-Slovaks from foreign domination." 89 Yet, the Americans, not yet a belligerent, still hoped for peace with Austria-Hungary in order to isolate Germany and end the war.

In Wilson's June 14th 1917, Flag Day Address, he recognized the Czechs in Bohemia as a people who didn't want to be part of the Austro-Hungarian Empire and wish to "direct their own affairs" and will only be satisfied by "undisputed independence."90 Even here, he didn'† acknowledge the AustroHungarian Empire as the oppressors of the Bohemians, but rather Germany which used Austria-Hungary and all its minority groups to its advantage in the

\footnotetext{
88 Woodrow Wilson as quoted in Unterberger, "Self-Determination," 930.

89 United States, Foreign Relations 1918, 8.

90 Wilson, "Messages and Papers," vol. 1, 415.
} 
war. In December of 1917, when asking for a declaration of war from Congress, Wilson stated:

(W)e do not wish in any way to impair or to rearrange the Austro-Hungarian Empire. It is no affair of ours what they do with their own life, either industrially or politically. We do not purpose or desire to dictate to them in any way. We only desire to see that their affairs are left in their own hands, in all matters, great or small.91

Immigrant groups responded by lobbying their liaisons in the government, stepping up their propaganda efforts, as well as volunteering for the United States Military. Even if they weren't able to join as a result of immigrant status, many joined the Czechoslovak Army on the Western Front. 92

On January $8^{\text {th }}, 1918$, Wilson delivered to Congress the famous Fourteen Points Speech of which Point Ten became the beacon of hope for Czechs and Slovaks living within the Austro-Hungarian Empire and abroad. Point Ten stated that "The peoples of Austria-Hungary whose place we wish to see safeguarded and assured, should be accorded the freest opportunity of autonomous development."93 Yet as both Allen Lynch and Betty Miller Unterberger have pointed out, this was not actually applying the principle of self-determination to

\footnotetext{
91 United States Department of State, Papers Relating to the Foreign Relations of the United States with the Address of the President to Congress, December 4, 1917, (U.S. Government Printing Office, 1917): xi-xii, http://digital. library.wisc. edu/1711. dl/FRUS. FRUS1917.

92 Chada, The Czechs in the United States, 51.

93 United States, Foreign Relations 1918, 15
} 
the ethnic groups in the empire. Instead it is calling for greater autonomy in a true federation of Austria-Hungary. ${ }^{94}$ Even so, Wilson became overwhelmed by the sheer number of ethnic groups which expressed their wishes for selfgovernment as a result of his declarations on self-determination. He stated:

When I gave utterance to those words, I said them without a knowledge that nationalities existed, which are coming to us day after day.... You do not know and cannot appreciate the anxieties that I have experienced as the result of many millions of people having their hopes raised by what I have said. 95

On May 29th, 1918, Robert Lansing announced that the "nationalistic aspirations of the Czechoslovaks and Jugo-Slavs for freedom have the earnest sympathy of (the United States) government."96 In the fall of 1918, Wilson finally conceded to dismantling the already disintegrating Austria-Hungary and referred to the empire as "an old building whose sides has been held together by props."97 This had more to do with the fact that ethnic groups all over the empire began to call for independence and there was nothing the Habsburgs could do about it at that point. Finally, on October 19th, 1918, President Wilson

\footnotetext{
94 Allen Lynch, "Woodrow Wilson," 428-9; Unterberger, "Self Determination", 935.

95 Woodrow Wilson as quoted in Derek Heater, National Self-Determination: Woodrow Wilson and His Legacy (New York: St. Martin's Press, 1994), 8.

96 United States, Foreign Relations 1918, 808-809.

97 Victor S. Mamatey, The United States and East Central Europe, 1914-1918: A Study in Wilsonian Diplomacy and Propaganda (Kennikat Press, 1972), 317.
} 
officially declared his support for a Czechoslovak state to Vienna and eventually stipulated Czech independence as a precondition to the armistice of 1918. Secretary Lansing expressed Wilson's support in these terms in a letter to the Swedish Foreign Minister:

Since (point ten of the fourteen points) was written and uttered to the Congress of the United States... the President is no longer at liberty to accept the mere 'autonomy' of these peoples as a basis of peace, but is obliged to insist that they, and not he, shall be the judges of what action on the part of the Austro-Hungarian Government will satisfy their aspirations and their conception of their rights and destiny as members of the family of nations. 98

Even as these events unfolded, Wilson didn't know a great deal about the actual situation in East Central Europe. As Allen Lynch explains, Wilson began to realize the "complexities of actually implementing the idea of national selfdetermination in East-Central Europe" which caused him to "express significant reservations about the concept himself." "99 He even stated,

When I gave utterance to those words (that all nations had a right to self-determination), I said them without a knowledge that nationalities existed, which are coming to us day after day... You do not know and cannot appreciate the anxieties that I have experienced as the result of many millions of people having their hopes

\footnotetext{
98 Woodrow Wilson, Messages and Papers," vol. 1, 541.

99 Lynch, "Woodrow Wilson and the Principle of 'National Self-Determination'," 425.
} 
raised by what I have said. 100

As a result, when the Paris Peace Conference began, Wilson and the Americans began to withdraw from actual decision-making with regards to issues of selfdetermination, and a new champion, France, stepped up its support for a Czechoslovak state. Yet Czechoslovakia still based a majority of its territorial arguments on Wilson's principle of self-determination and, as a result, the idea of Wilson as its champion lives on.

As a result of Czechoslovak independence, the Czechs and Slovaks believed that Wilson was their liberator. 101 Yet, President Wilson told Charles Pergler: "By your conduct throughout the war, especially by your armies, you have demonstrated that you insist upon complete independence. WE have merely recognized an accomplished fact."102 Wilson thus gave the immigrant groups credit for Czech independence as a result of their efforts to make contacts in Congress and organize speeches an sway American public opinion on the matter of Czecho-Slovak independence. However, independence wasn't the only goal of the Czech diplomats; next they had to secure the borders of the new state, which proved equally as difficult as gaining American

100 Woodrow Wilson as quoted in: Lynch, " "Woodrow Wilson and the Principle of 'National SelfDetermination'," 426.

101 Mamatey, "The Establishment of the Republic," 20.

102 Charles Pergler, America in the Struggle for Czechoslovak Independence (Philadelphia,

1926), 55-56. 
support for independence.

\section{Border Disputes and Minorities Within Czechoslovakia}

As the Austro-Hungarian Empire broke up at the conclusion of World War I, several states emerged in Eastern Europe along ethnic lines, basing their claims on President Woodrow Wilson's policy of self-determination. However, ethnic boundaries were not clear from the start and, as a result, border disputes over former Austro-Hungarian territory emerged. In the 1921 Czechoslovak census, which used mother tongue as a basis for determining nationality, Czechoslovakia contained a combined ethnic minority population of $34.49 \%$ of the total population. 103 A large portion of these minorities, with the exception of ethnic Germans, lived in contested areas of Silesia, Slovakia, and Ruthenia. In Czechoslovakia, the Czechs and Slovaks only made up about 65 percent of the country's total population; therefore, it became more effective to use historical and linguistic arguments to establish borders as opposed to demographic ones. 104

\footnotetext{
103 Joseph S. Roucek, "Czechoslovakia and her Minorities," in Czechoslovakia Twenty Years of Independence, ed. Robert J Kerner (Berkeley: University of California Press, 1940), 174. This chapter contains an excellent table which, based on census records, shows nationalities living in Czechoslovakia in 1910, 1921, and 1930.

104 Stephen Borsody, The New Central Europe: Triumphs and Tragedies (New York: Columbia University Press, 1993), 3.
} 
After World War I, the new Czechoslovak state began again to use historical arguments to justify border claims. However, while the border regions they claimed had, in fact, historically been a part of the Bohemian crownlands, they had since been settled by non-Czechs. Like Czechoslovakia, "many of the 'new' states in the region wanted their 'old' borders to be reestablished, and this objective became a source of conflict among neighbors, because the historical borders either had been fluid throughout the ages or did not correspond to national borders in the ethnic sense of the word." 105

Predominantly German-speaking provinces such as Sudetenland, Deutsch-Böhmen, and Deutsch-Sudmähren became part of the new Czechoslovak state in order to "unite them with the rest of the country and strengthen Czechoslovak territorial claims at the Paris Peace Conference." 106 It was also argued that the only reason why Germans made up significant minorities in these provinces was a result of Bohemian nobles' invitation to German colonists to work, or German migration to "traditional" Bohemian lands as a result of White Mountain. Thus, history was put to work again in legitimizing and justifying border claims and disputes.

Though the Western allies had no clear policy when it came to border disputes, some had specific agendas. France, for example, saw a strong

\footnotetext{
105 Johnson, Central Europe, 28.
}

106 Wingfield, Flag Wars, 140. 
Czechoslovak state as a future ally against a common enemy, Germany. Therefore, the French set out to secure strategically and economically favorable frontiers for the Czechoslovak state; however, they also wanted a giant buffer zone, and even a confederation of states made up of Czechoslovakia, Yugoslavia, and Poland. While the United States made sure Czechoslovakia gained independence; they didn't have much to do with the actual decisions on the settlement of borders. The British preferred to remain largely out of the decision-making on East-Central European borders as they were preoccupied elsewhere. Thus, the Czechs were free to seize territory which they considered theirs by historic right as the "territorial limits of the states were determined piecemeal by the Big Four, who never fitted the fragments together or considered the influence of their decisions on the political and economic balance of the area." 107

In order to incorporate Slovakia and Ruthenia, Masaryk and Beneš turned to Wilson's principle of self-determination. Masaryk argued that the Slovaks and Ruthenes wanted to be free of Hungary and be part of the democratic federation of Czechoslovakia. Ironically, France proved to be the real ally of Czechoslovakia at Paris, not the United States, and as a result Czechoslovakia achieved nearly all of its territorial demands.

107 Perman, Czechoslovak State, 75. 
At the Paris Peace Conference, Beneš argued for Czechoslovak borders in the north to be based on historical right and economics. In the case of Těšin (Teschen in German, or Cieszyn in Polish), the Czechs wanted to control the economically prosperous coal region of Austrian Silesia, which also happened to correspond to the historic medieval borders of Bohemia-Moravia. Additionally, Czechoslovakia claimed that the only railway to connect the western part of the newly formed country with Slovakia was located in the Těšín region.

Unfortunately, this conflict also led to a break-down in relations as well as hostilities between Poland and Czechoslovakia, particularly over their shared border. Both states had a legitimate argument for the possession of Těšin. Poland argued that this city had a Polish majority (around 55\%), and Czechoslovakia argued for its strategic importance to the new country as well as that it had historically belonged to the Bohemian crownlands. Linguistically, when this area of Silesia was under Habsburg rule, "German served in most capacities as the administrative language; there were no fixed or obvious borders of Polish and Czech language and culture in Těšín Silesia." 108

Těšin was also valuable to both countries' economies due to the presence of a large urban industrial center surrounded by coalfields as well as a strategic railway point. Therefore, on January 23rd, 1919, after much dispute about the

108 Kevin Hannan, "Language and Ethnicity Among Students in Český Těšín Silesia", Nationalities Papers (1999), 201. 
status of the region, Czech troops invaded the Polish portion of Těšin and captured the city. This resulted in an armed confrontation until February $5^{\text {th }}$, 1919. Despite Allied involvement, it was still determined that Czechoslovakia and Poland should solve the dispute themselves; however, neither side was willing to give up their claim to the entire region. Eventually, despite attempts at a plebiscite, the Council of Ambassadors, part of the League of Nations for treaty compliance, decided the border which was signed into effect the Spa Conference in Belgium in July 1920.

In 1920, the League of Nations determined that the city to the north belonged to Poland and the coalfields and railway lines to the south belonged to Czechoslovakia. However, neither side was happy with this resolution since each lost part of Těšín and both sides claimed the entire region. Sir James Roy, a British diplomat sent to ensure the peaceful transfer of the city of Těšin to Poland in 1920, explained that "as to the possibility of rapprochement between Czech and Pole, this is for the moment impracticable. Both are incapable of thinking in terms other than local; their vision is circumscribed by urgent problems of social reconstruction and irritating questions of boundary delimitation." 109

109 James Roy, Pole and Czech in Silesia (London: John Lane Company, 1921), 9-10, http://hdl. handle.net/2027/uc2. ark:/13960/†4gm84q7x. 
Ultimately, Czechoslovakia obtained almost all border claims, including the majority of the province of Těšín. One way to understand this decision is that Masaryk and Beneš appealed to the democratic principles that had supposedly guided the Allies in World War I. Their argument of democratic exceptionalism and national self-determination on the basis of "historic rights," coupled with the Czech émigré communities lobbying key members of the Allied governments and the League of Nations, resulted not only in the granting of statehood, but border claims as well. It also helped that the personalities and rhetoric of the Czech politicians appealed to the Allies. In Peacemakers: The Paris Peace Conference of 1919 and Its Attempt to End War, Margaret Macmillan explains the effectiveness of Czech claims to democratic exceptionalism in the eyes of Entente diplomats:

The Poles were, of course, dashing and brave but quite unreasonable, the Romanians charming and clever, but sadly devious, the Yugoslavs, well, rather Balkan. The Czechs were refreshingly Western... Beneš and Masaryk were unfailingly cooperative, reasonable and persuasive as they stressed the Czech's deep-seated democratic traditions and their aversion to militarism, oligarchy, high finance, indeed all that the old Germany and Austria-Hungary had stood for. 110

Beneš worked diligently attempting to win over the Allies in Paris. His effort was rewarded when he sat on the Supreme War Council when no other

110 Macmillan, Peacemakers, 240. 
representatives of Central or Eastern European states were invited. In the long run, the main problem with the borders which he secured proved to be the large ethnic minorities which now resided within the Czechoslovak state.

Ultimately, almost every Czechoslovak border claim was granted; however, this proved to be a mixed blessing. Gaining the historic Bohemian lands meant that Czechoslovakia would also gain large and diverse minority populations which proved to be problematic later. The ethnic minority situation didn'† change much from Austrian administration to Czechoslovak, except that now the Czech nationalists were in a position to enact laws which furthered their Czech-centered goals. Once again, there didn't seem to be any room for autonomy of national minorities, even though Czechs and Slovaks knowingly pursued borders which would create a multi-ethnic state. However, as Tony Smith explains, during the inter-war period, the multi-ethnic character actually helped contributed to Czechoslovakia's successful maintenance of a democracy. The sheer fact that the Czechs and Slovaks always had to compromise with each other made it difficult for a single national group to gain hegemony which helped the plurality of Czechoslovak democracy. ${ }^{111}$

Masaryk, the first president of Czechoslovakia, consciously intended for Czechoslovakia to be a multi-ethnic state. However, once again the promotion

111 Smith, America's Mission, 101. 
of Czech interests above all others as a legacy of the Czech-German conflicts during the late Habsburg Empire encouraged the exclusion of any other identities aside from that created by Czech nationalists. For example, Slovaks were encouraged to be proud of their heritage; however, it was their invented "Czech" heritage that was intended.

Increasingly, the Czech government turned to legal means now that they were available in order to nationalize its citizens and begin the process of "Czechification."112 The government sanctioned the migration of Czechs into predominantly German areas in order to gain a more legitimate foothold in these German-speaking regions of the new Czechoslovak state. Interestingly enough, although Germans were recognized as non-Czech, they could still become Czech just by speaking the language. Thus existed continuity from the Austro-Hungarian Empire between these two created identities for a sizeable portion of the population. The situation for Jews didn't change as a result of the change in regime. Their association with, and frequent assimilation into German culture caused Czech nationalists to criticize them and view them as "agents of Germanization in nationally contested regions." 113

After World War I, comprised of Bohemia, Moravia-Silesia, Slovakia,

\footnotetext{
112 This term is used by Cornwall as an artificial means of national identity, in other words, not a naturally occurring phenomenon but a forced one; see Cornwall, Language Border, 923.

113 Zahra, Kidnapped Souls, 22.
} 
Ruthenia and the Sudetenland, Czechoslovakia controlled a pivotal central location in Europe. Bohemia not only provided the unity necessary to keep these parts of Czechoslovakia together but seemingly protected the integrity of Europe as well. Recognizing Bohemia's geopolitical significance in the late nineteenth century, Bismarck declared "whoever is the master of Bohemia is the master of Europe," adding that "the boundaries of Bohemia are the safeguard of European security." In his mind "the Czech nation does not lust for domination" therefore their continued presence in Bohemia protected Europe from plunging into chaos. Conversely he asserted that any adventurers who attempted to violate the sovereignty of Bohemia would "plunge Europe into misery." 114

Bismarck's statement reigned true in 1938, when the Czechs lost control of the Sudetenland to Hitler as a result of the Munich Agreement, which paved the way for the subsequent Nazi takeover of all of Bohemia. Consequently, all of Europe was plunged into chaos. However, where was this special relationship between the Czechs and Americans now? The United States government explained the situation as follows:

Because of its geographic isolation deep in Central Europe and the emergence of a powerful Nazi Germany and Communist Russia

\footnotetext{
114 Mastny Vojtech, The Czechs Under Nazi Rule: The Failure of National Resistance (New York:
} Columbia University Press, 1971); Jaroslav Cisar, The Role of Czechoslovakia (London, 1944), 9. 
on its borders, Czechoslovakia was never to have Western support sufficiently strong to guarantee its national independence and territorial integrity. Essentially the Czechoslovaks have been left to fend for themselves in one of the most politically sensitive areas of Europe. 115

Though Otakar Odlozilik is quick to point out that Wilson took much longer to support the Czecho-Slovak independence aims than other Allied powers, in fact didn't matter or register with the Czechs. It also didn't matter that Wilson didn't actively support Czech border claims in Paris. When Masaryk finally returned to a newly formed Czechoslovakia as its president he returned to fanfare and a belief that President Wilson and the United States would always be the Czechs' guarantor of independence. Thus began a time period where portraits of Wilson "were to be seen not only in public buildings along with those of Masaryk but also in private homes - evidence of the belief that President Wilson was the best friend of Czechoslovakia, the chief promoter among the Allies of its interests and aims." 116

115 Library of Congress, Background Materials, LRS-10.

116 Odlozilik, "The Czechs," 223; See Appendix for postcards of this phenomenon. 


\section{Chapter 4}

\section{Case Study: Wilson in Czech Memory and Monumental Politics}

In 1923, Masaryk sent the dying Wilson two photo albums with pictures of all the public places that the Czech people had named for him, such as streets and squares. There were postcards commissioned in his honor as well with images of both Masaryk and Wilson on them (see appendix). When Wilson passed away in 1924, the Czechoslovaks held services in his honor in Prague and Beneš gave a speech about the importance of Wilson to the Czechoslovak state. ${ }^{117}$ The biggest honor came in the form of a statue in Prague opposite the Wilson Railway Station in 1928. What was the meaning and intent behind this site of memory, and what narrative of the past does this monument represent? With the vast expansion of the field of memory studies, it is important to be clear about what one is discussing.

\section{Theory - What Type of Memory?}

The type of memory addressed here is collective and takes the form of political or national memory. Jeffrey Olick explains that "memories... are as much the products of the symbols and narratives available publicly - and of the social means of storing and transmitting them - as they are the possessions of

117 Special Correspondence, "Czechs will Unveil Memorial to Wilson," New York Times (July $1^{\text {st }}$ 1928). 
individuals." 118 He then differentiates between two types of memory: collected and collective. Collected memory is collectively framed individual memory attached to experience, since it is understood that individual memory does not occur in a vacuum; however, collective memory is shared memory which is detached from personal experience and reattached to an external site, such as monuments. Alaida Assmann differentiates memory into individual, social, political, and cultural categories. Individual and social memory falls under Olick's "collected memory" category, whereas political and cultural memory falls under his "collective memory" category. Specifically, Assmann explains that political memory is "how memories are used for political action and the formation of group identity" and can be established by certain practices, such as the erection of monuments, which stabilize this memory in a way that can be passed on over time. 119

Assmann's categorization of political memory can be further understood as the process by which political actors use tools and mechanisms to construct memory and therefore create a national narrative in order to facilitate a particular national identity construction. This process is what Jan-Werner Müller refers to as collective national memory which best exemplifies the relationship

\footnotetext{
118 Jeffrey Olick, "Collective Memory: The Two Cultures," Sociological Theory 17.3 (1999): 335. 119 Aleida Assmann, "Four Formats of Memory: From Individual to Collective Constructions of the Past," in Cultural Memory and Historical Consciousness in the German-Speaking World Since 1500, eds. Christian Emden and David Midgley (Oxford: Peter Lang, 2004), 25-26.
} 
between memory and politics or power. He explains that "memory itself is a kind of 'symbolic power', which can be marshaled in much the same way as material power." 120 He also establishes two links between memory and power: legitimacy and interest. This study focuses on legitimacy which is how "policies are legitimated through appeals to the collective or national memory for social consumption both at home and abroad."121 What Müller calls collective national memory, Duncan Bell calls myth. These myths are "highly simplified narratives ascribing fixed and coherent meanings to selected events, people, and places, real or imaginary." 122 Bell contends that "the forms assumed by mythscapes," which can include monuments, "are always the result of power, and the struggle over interpretation of the past." 123

Furthermore, there are various ways in which this national political memory can be studied: top-down or bottom-up. According to Assmann, a bottom-up approach "looks at individuals in specific historical situations, investigating how memories are established and communicated;" whereas, a top-down approach "examines collective units... and asks how memories are used for

\footnotetext{
120 Jan-Werner Müller, ed, Memory and Power in Post-War Europe, ( Cambridge, 2002), 25

121 Müller, Memory, 26

122 Duncan Bell, "Agonistic Democracy and the Politics of Memory," Constellations 15. 1 (2008): 151.

123 Bell, Politics, 151.
} 
political action and the formation of group identity. "124

When examining this top-down approach, it is important to look at the landscape or sites where power and identity are negotiated. One such site is the monument; however, it is important to first make the distinction between monuments and memorials. Robert Ivy explains that though both monuments and memorials involve place as well as remembrance, "fundamentally a monument comprises a designed and constructed physical object intended as a commemoration;" whereas, memorials "may take on a more ephemeral form." 125

When discussing landscape and sites of memory O'Keefe distinguishes between "visual-factual" memories and "sensual-emotional" memories and posits that the landscape can be "a touchstone for remembering both." 126 "Sensual-emotional" memories can be personal experiences of an event; whereas "visual-factual" memories can be the external site or political representation of the event to the public. He explains that memories which appear or disappear "do not simply emerge out of thin air... but result directly from people's commemorative decisions and actions as embedded within and

\footnotetext{
124 Assmann, Memory, 25.

125 Robert Ivy, "Memorials, Monuments, and Meaning," Architectural Record 190.7 (2002): 84.

126 Tadhg O'Keeffe,, "Landscape and Memory: Historiography, Theory, Methodology," in Heritage, Memory and the Politics of Identity: New Perspectives on the Cultural Landscape, eds. Niamh Moore and Yvonne Whelan (Aldershot, UK: Ashgate, 2006), 5-6.
} 
constrained by particular sociospatial conditions." 127 Thus, specific memories can be constructed at certain sites where commemorative action has been taken.

\section{The Case of the Wilson Monument in Prague: Background and Analysis}

On July $4^{\text {th }}, 1928$, a statue to the American president Woodrow Wilson was unveiled in Prague opposite the Wilson railway station (seen Figures 2 and 3 in Appendix). Beneš, the Foreign Minister, stated at the dedication, "our people understood and appreciated President Wilson and his native land... he was for a long time their strengthening consolation and hope, their helper and friend, and today he will be their model of a citizen and a democrat."128 Americans of Czechoslovak descent raised the money for the statue and a Czech American, Albin Polasek, built the statue which was commissioned by the Czechoslovak National Council of America. It is also worth noting that he built the Masaryk Memorial in Chicago in 1941.129 At the base of the statue to the deceased American president, the inscription stated "The world must be made safe for democracy," a Wilson quote. On July $4^{\text {th }}, 1928$ at the unveiling of the statue, the

127 Ruben Rose-Redwood, "Collective Memory and the Politics of Urban Space: An Introduction," GeoJournal 73 (2008): 161.

128 New York Times, "Czechs Will Unveil Memorial To Wilson" New York Times, July 1, 1928, Special Correspondence.

129 There is also a Masaryk memorial in Washington DC near Dupont Circle in front of the Luxembourg Embassy which was gifted by the American Friends of the Czech Republic September 19, 2002. 
Czechoslovak Deputy Premier "spoke of the nation's gratefulness to Wilson." 130 Massive amounts of Czechs in the newly formed Czechoslovakia turned out at the unveiling to show their appreciation and enthusiasm for the American President (see Figure 1 in Appendix). However, the statue didn't remain in place for very long and under Nazi occupation this statue was torn down in 1941.

Ironically, Hitler used Wilson's self-determination rhetoric when arguing for the Sudetenland before and during the Munich Conference. After taking over the Sudetenland due to European appeasement policies, Hitler invaded Czechoslovakia and created the Protectorate of Bohemia and Moravia, recognizing a separate and truncated Slovak state. After the United States formally declared war on Germany December $11^{\text {th }}, 1941$, the Nazi leader of the Protectorate, Reinhard Heydrich, had the Wilson statue removed and destroyed the next day. At the conclusion of World War II, the plaque with its Wilson quote, however, was placed again where the statue had once stood. Yet again, the Soviets, another foreign power whose ideals didn'† line up with Wilson removed the plaque after the communist takeover of Czechoslovakia in 1948. In the 1970s, the Czechoslovak communist regime went one step further and ordered that all the original casts be destroyed.

After the fall of the Czechoslovak communist regime, the founder of

\footnotetext{
130 Special Cable "Prague Dedicates Wilson Monument," The New York Times (July 5, 1928).
} 
American Friends of the Czech Republic, Robert Doubek, went to work raising the funds and searching for the missing original casts which had reportedly been destroyed by the Czechoslovak communist government during the Cold War. Miraculously, even after having signed off on destroying the casts, someone saved the head and buried it in the national archives. ${ }^{131}$ Thereafter, the new Czech government paid for the base of the statue, and the American Friends of the Czech Republic paid for the statue itself. The replica of the original statue was commissioned in 2009 and unveiled in Prague in 2011. Debbie Komanski, executive director of the Albin Polasek Museum stated:

It's an extremely, extremely important symbol of the friendship between our nations and our common commitment to making the world safe for democracy. The Nazis may have destroyed it, the Soviets took their shot at it, but it will be unveiled again. ${ }^{132}$

This statue can be seen as a means to bind Czechoslovakia to the United States in the memories of the Czechoslovak people in order to create political legitimacy. Müller's link of memory-power to legitimacy is important for understanding the politics behind the Wilson statue. Not only can policies be legitimized through memory, but nations and their relations can be legitimized through memory. In this example, the statue of Wilson in Prague in 1928 not only

131 Matthew J. Palm, "Polasek Legacy: Sculptor's Democracy Statue Returns to Prague," Orlando Sentinel (October 3, 2011).

132 "Polasek Legacy," Orlando Sentinel 
serves the purpose of legitimizing the new nation of Czechoslovakia, but also establishes and legitimizes the relationship between Czechoslovakia and the United States of America. Its reestablishment in 2011 is a continuation of the legitimization of the relationship between the newly divorced nation, the Czech Republic and the United States. It was especially important to establish a democratic link to the United States after being a communist-ruled state for the better part of the late twentieth century. Thus, the constructed political memory of Wilson's role in the formation of former Czechoslovakia takes physical form in this site of his monument.

Why construct this type of monument in Prague? Sanford Levinson explains that, "changes in political regime often bring with them changes in the organization of public space; states always promote privileged narratives of the national experience and thus attempt to form a particular kind of national consciousness." 133 The Czech elites of 1928 were attempting to do just this through a top-down approach where their political actions and legitimacy were basically legitimized through the Wilson statue; and thus they were the rightful rulers. While American civil society groups largely funded both versions of the statue, the Czech government on both occasions agreed to its placement as a way to nurture good Czech-U.S. relations. As Petrina Dacres asserts,

133 Sanford Levinson, Written in Stone: Monuments in Changing Societies (Durham NC: Duke University Press, 1998), 10. 
"monuments participate in establishing the legitimacy and authority of the state" and are "produced through a process of political negotiations, are developed into symbols of cultural solidarity." 134 This monument aided in establishing this legitimacy and served as a reminder of that authority.

The statute also shows how the landscape can be used for political means in order to further one interpretation of the past, even at the expense of other interpretations. As Assmann explains, political memory is anchored in the material. Therefore, this statue serves as a site of political memory where "policies are legitimated through appeals to the collective or national memory for social consumption both at home and abroad." 135 Both in Czechoslovakia, and later the Czech Republic, as well as in the United States, this statue is a site which ties the Czech people to the American people. In addition, it connects the Czechs to the American democratic tradition and the principles which Wilson held. It also holds special meaning for descendents of Bohemia living in the United States which see this site of memory as a link to their ancestors' homeland.

On the other hand, the statue could have been unveiled in 1928 as a response to the growing uncertainty in the world around them. Indeed, during the unveiling, sentiments were expressed such as the hope that "Wilson's

\footnotetext{
134 Patrina Dacres, "Monument and Meaning," Small Axe 16 (2004): 137-8.

135 Müller, Memory, 26
} 
idealism would one day be realized despite the war's aftermath of dictatorships which prevail in parts of Europe;" and, "as long as the hodgepodge map of Europe remains as it is, there will always be one little country where nothing but praise will be said for America's war-time President." 136 Therefore, this monument could also serve to bind the Czechoslovak-American relations in the memories of Americans as well. There was legitimate fear and uncertainty about the future of Czechoslovakia, and thus the Czech elites may have attempted to bind the political memories of these two nations in the hope of future favorable political action.

Another interesting aspect of the Wilson monument was its removal by Reinhard Heydrich during the Nazi occupation of Czechoslovakia. Altering landscape isn't just about what kind of political memory to impose, but also about what kind of memory to forget. As Levinson explains, "those who overthrow regimes often take as one of their first tasks the physical destruction of symbols - and the latent power possessed by these markers - of those whom they have displaced." 137 Therefore, the removal of the Wilson monument by Heydrich attests to the actual power of this monument in the Czech politicalnational memory.

\footnotetext{
136 New York Times, "Prague Dedicates Wilson Monument," New York Times, July 5, 1928, Special Correspondence.

137 Levinson, Written in Stone, 12.
} 


\section{International Relations and Memory?}

In a lecture in 2005, the Czech ambassador to the United States, Martin Palouš, "traced current relations back to the end of the First World War when the United States 'helped decisively with the creation of a democratic Czechoslovakia,' and he continually referenced the need to build upon those foundations in the pursuit of a continued relationship."138 Then on September $8^{\text {th }}, 2011$, a new statue of Wilson was raised in the same location as the old statue.

At the unveiling of the new statue in 2011, the Czech ambassador to the United States, Petr Gandalovic stated that the statue is "an opportunity to commemorate the importance of the United States of America in the creation of independent Czechoslovakia."139 Prominent Czech magazines such as Prague Leaders Magazine, the Prague Monitor, the Prague Post, and Radio Prague all covered the resurrection of the statue and its subsequent unveiling. Prague Leaders Magazine even placed a clip of the unveiling and the weeklong festivities surrounding the event on its YouTube channel. ${ }^{140}$ The

\footnotetext{
138 Donald Hempson, "The Lion with Two Tales: Czechoslovak Economic and Foreign PolicyMaking and Its Impact on U.S. Relations, 1919-1929," (PhD diss., Ohio State University, 2006), 7. 139 Patricia Sullivan, "Prague Honors Woodrow Wilson," The Washington Post, October 6, 201 1, Metro section, Suburban edition.

140 The Prague Monitor, accessed April 16 th , 2014, http://praguemonitor. com/201 1/09/09/wilsonsstatue-returns-prague; The Prague Post, accessed April 16 th , 2014, http://www. praguepost.cz/ tempo /5848-wilson-statue-step-closer-to-completion.html; Radio Prague, accessed April 16 th,
} 
interesting thing about the 2011 unveiling of the Wilson statue on YouTube is that it shows the popular enthusiasm and large crowds which appeared for the statue's unveiling. As a result of its presence on the internet, this production and interpretation of the past won't go away any time soon.

The United States Embassy in Prague also posted a clip on YouTube of Ambassador Norman Eisen speaking at the unveiling in which he states that the statue is "not only a physical structure, but also a monument in (the Czech people's) hearts." 141 He goes on to state that the monument is indicative of the close ties between the United States and the Czech Republic and symbolizes the many immigrants from Bohemia to the United States. Essentially, Ambassador Eisen enumerates the myth of the statue and the political-symbolic importance for both the Czech peoples and the American peoples today. Thus this resurrected statue of Wilson is furthering the myth of the creation of Czechoslovakia and the myth of Wilson in the Czech Republic itself as well as presents the Czech Republic as a distinctly Western state which is perpetuated by both the Czech government and immigrant groups in the United States.

2014, http://www.radio.cz/en/section/curraffrs/woodrow-wilson-statue-returns-to-prague-after70-years; Prague Leaders Magazine, accessed April 16 th , 2014, https://www. youtube.com/ watch?v=vcxbO_xpOBc.

141 "Ambassador Eisen Remarks at the Woodrow Wilson Dedication Ceremony," US Embassy Prague, accessed April 16 th , 2014, https://www. youtube.com/watch?v=IRNZGEW5-00. 
As Müller states, "memory is not a vessel of truth or a mirror of interests, but a process of constructing meaning." 142 This meaning can take a variety of forms such as monuments and can be a place where nationhood is legitimized and national-identity is constructed and shared. It can also be a place to attempt to influence relationships between countries by linking the two based on shared democratic values and historical circumstances. The Wilson statue is a site of ongoing political and national memory construction with numerous layers which are as telling about Czech national identity and politics as they are about Czech-American foreign relation strategies.

142 Müller, Memory, 30. 


\section{Conclusion and Consequences for Today}

The communist takeover of Czechoslovakia in 1948 marked the beginning of another chapter in Czech-American relations; however, it proved to be much more limited than before. The CNCA was initially active in lobbying the United States government to liberate Czechoslovakia from the communists. Yet the émigré organization began to disintegrate shortly thereafter due to infighting as to what course of action the Council should take. A much smaller Council began to help Czech expatriates find places in the United States to live and work. This phase consisted mostly of Czech-Americans financially helping Czechs who wanted to leave their now communist-ruled country.

There were still other civil society groups of Czech descent in the United States, some of which exist in the present; what follows are just a few of the many. The American Fund for Czechoslovak Relief (AFoCR) was established in 1948 to provide aid and relief to Czechoslovakia during communism. This group terminated its activities in 1990. The American Friends of the Czech Republic (AFoCR) states on the website that its mission is to: "foster() closer ties between the United States and the Czech Republic in the areas of business, trade, 
culture, education, diplomacy, and security." 143 This organization was also responsible for building the Masaryk Memorial in Washington, D.C., the reerection of the Wilson Statue in Prague, as well as financially assisting the Czech Republic after the floods of 2002. It also supported the entry of the Czech Republic into NATO.

The Council of Free Czechoslovakia, formed in 1949, became the Czech and Slovak Solidarity Council in 1994 after the Velvet Divorce to promote good relations between the Czechs and Slovaks. The Wilsonian Club, founded in 1949 by Czech- and Slovak-Americans originally commemorated the memory and legacy of Wilson in his part of the independence of Czechoslovakia. Today its goal is to commemorate his legacy all over the world.

Aside from these groups, there has been collaboration between the Czech Republic and the United States on several occasions. Politically, the Czech Republic was a staunch supporter of the United States during the Iraq invasion and during the war on terror. Most recently, a fertilizer plant exploded in the town of West, Texas. Devastated by the explosion, West, inhabited primarily by people of Czech descent, was initially denied FEMA assistance.

As a result of the destruction, the Czech Republic stepped in to help by

143 "Mission," American Friends of the Czech Republic, accessed on January 15, 2014, http://www.afocr.org/mission. 
approving the donation of $\$ 200,000$ to the town of West. The Czech ambassador to the United States, Petr Gandalovič "travelled to West immediately after the explosion to personally express his condolences to those affected by the blast." 144 He even remarked that in the Czech Republic, "this story is the NO.1 news item and tops social media discussions." 145 It is easy to see how, to this day, the legacy and memory of Czech-American cooperation based on Wilson and Czech immigrants still permeates the relationship between these two nations.

In the end, the words of President Tomáš Masaryk still ring true in the Czech Republic:

Your name, Mr. President, as you have no doubt read, is openly cheered in the streets of Prague our nation will forever be grateful to you and to the people of the United States. And we know how to be grateful. Believe me, Mr. President, Yours very sincerely. Th. G. Masaryk ${ }^{146}$

Woodrow Wilson's legitimization of the Czechs claim to self-determination during

144 "Explosion in West, Tx - Czech Government Approves Aid," Embassy of the Czech Republic in Washington, D.C., accessed on January 15, 2014,

https://www.mzv.cz/washington/en/czech_u_s_relations/news/explosion_at_a_plant_in_west_tx. html; B.C. , "The Czech Roots of a Town in Texas," The Economist Blogs, accessed on January 15, 2014, http://www.economist.com/blogs/easternapproaches/2013/04/czech-republic-andamerica.

145 Jessica Ravitz, "Town Devastated by Fertilizer Explosion is Guided by the West Way," CNN, accessed on January 15, 2014, http://www.cnn.com/2013/04/24/us/west-texas-profile. 146 Kovtun, Masark \& America, 59. 
World War I, established the United States president's role in the creation of Czechoslovakia regardless of any misgivings he may have had during the process. The success of the Czech nationalists and Czech immigrant civil society groups in using historic right to achieve foreign and domestic policy aims is unique; however, the legacy of Woodrow Wilson as he lives on in Czech politics is also exceptional in history. This legacy can be seen through the case of the Wilson Monument in Prague and its resilience as a symbol of democratic freedom to the Czech people. 


\section{Appendix}

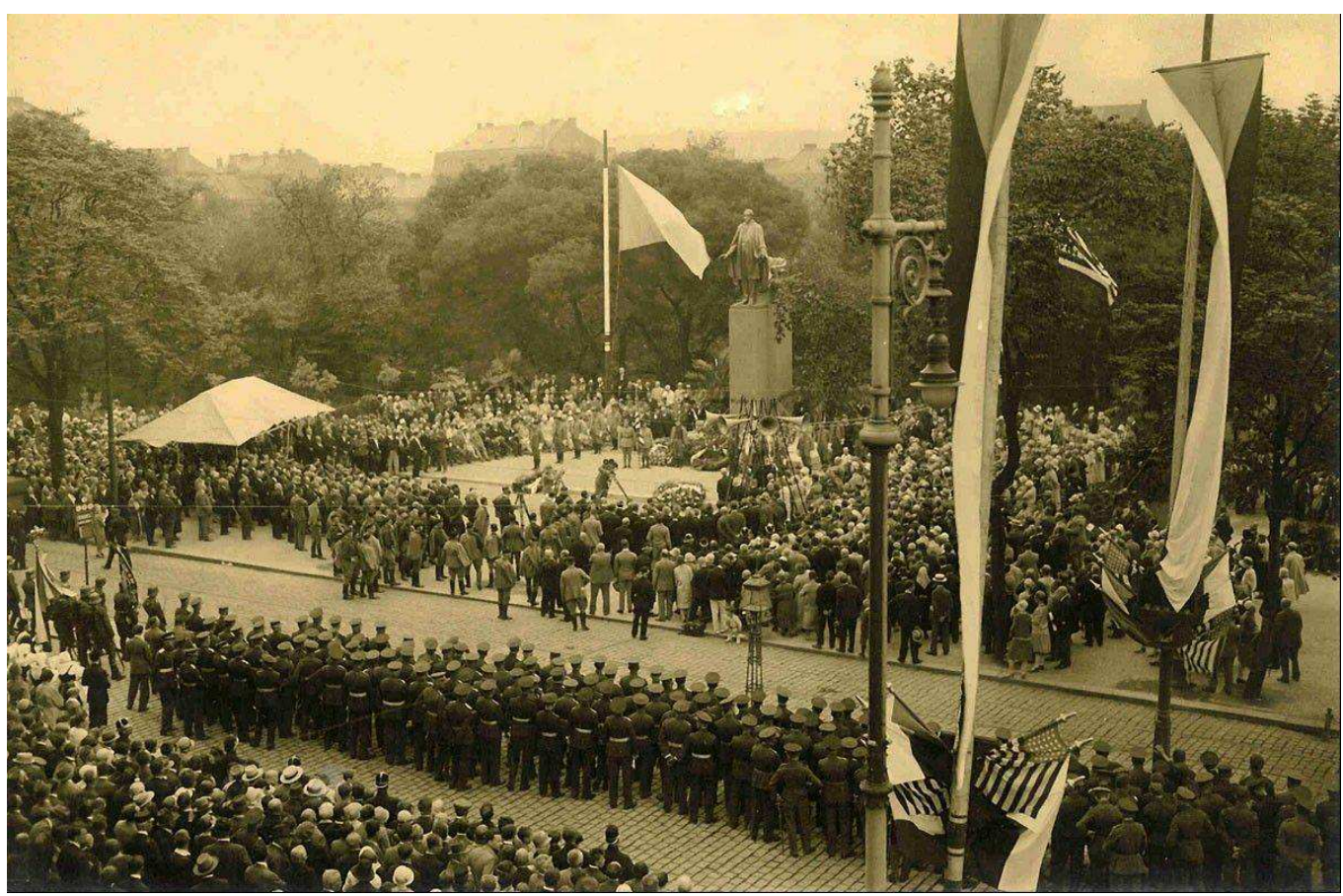

Figure 1 - Czech crowds at the original Wilson statue's unveiling in 1928.147

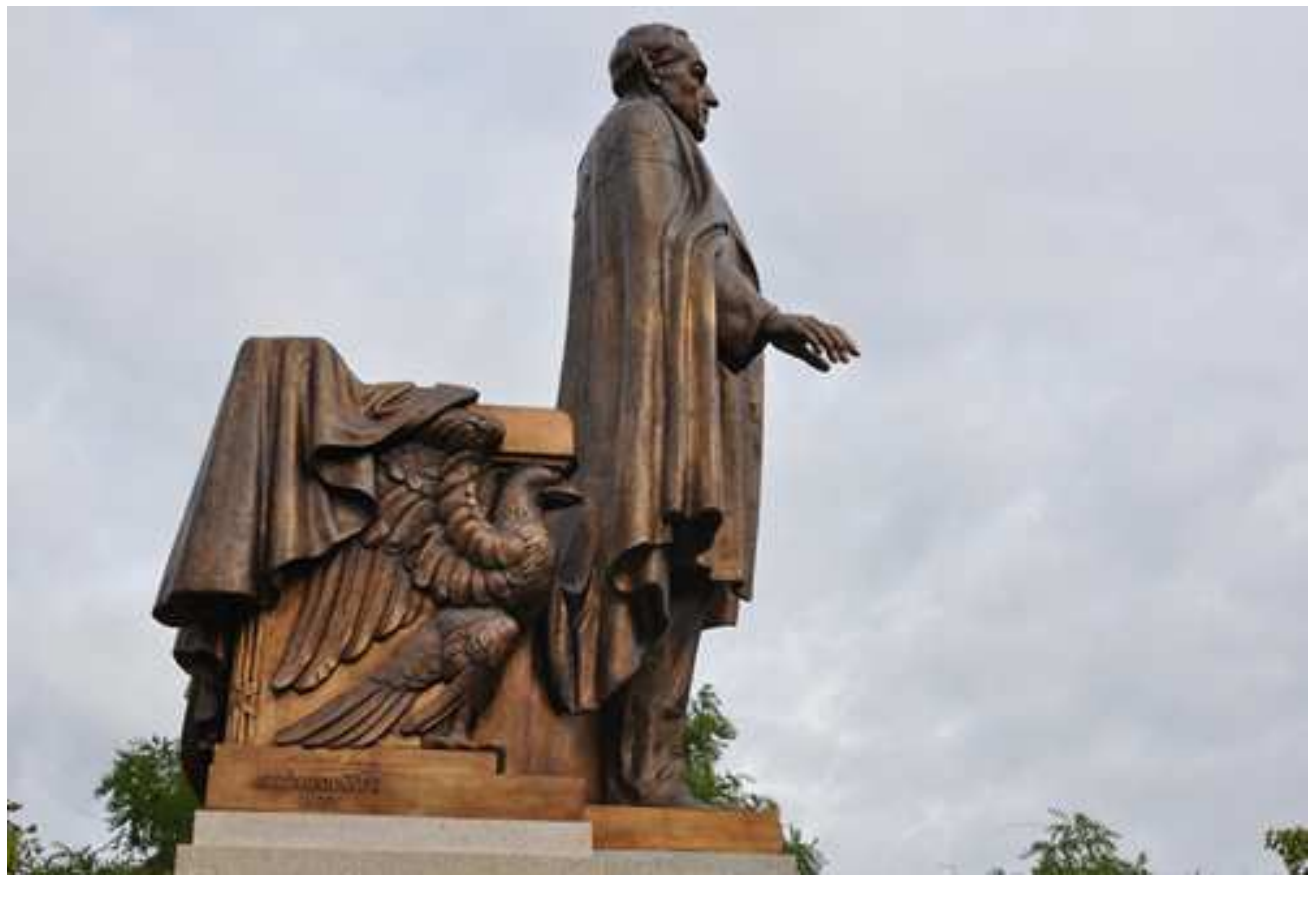

147 The Washington Post, http://www.washingtonpost.com/local/prague-to-honor-woodrowwilson-with-new-statue-at-main-train-station/201 1/09/29/glQAeghoLL_story.html. 
Figure 2 - 2011 Wilson statue in Prague 148

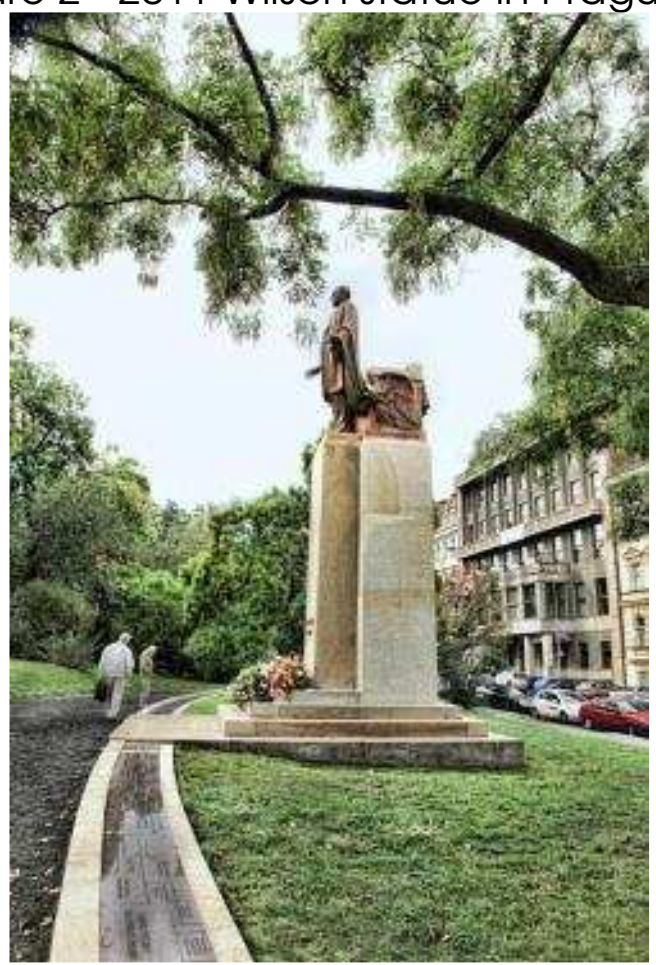

Figure 3 - 2011 Wilson statue in Prague 149

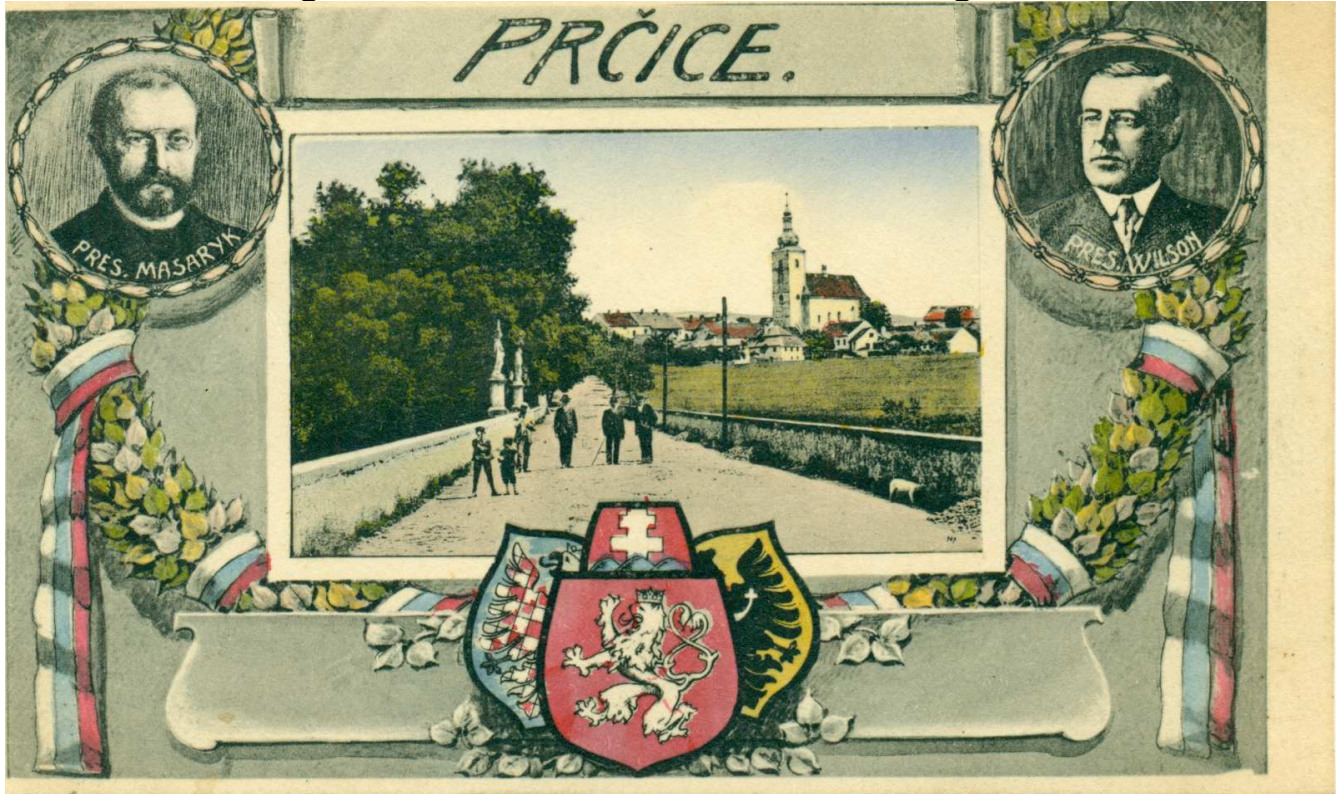

Figure 4 - Tomáš Masaryk and Woodrow Wilson on a Czech postcard (Personal Collection)

148 US Embassy, http://prague.usembassy.gov/woodrow-wilson-monument-unveiled-inprague.html.

149 American Friends of the Czech Republic, http://www. afocr. org/wilson-monument-and-tgmasaryk-memorial. 


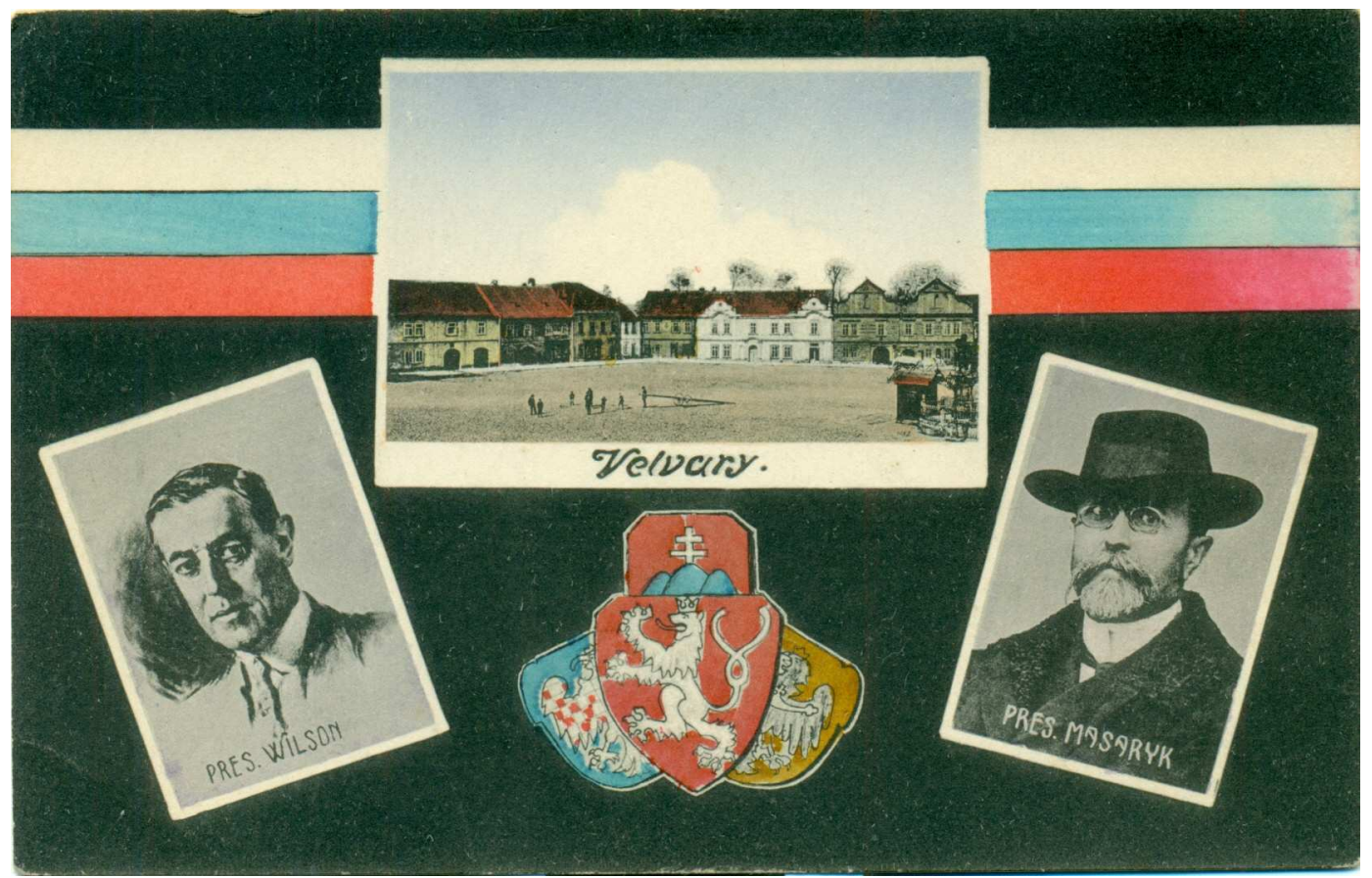

Figure 5 - Woodrow Wilson and Tomáš Masaryk on a Czech postcard (Personal Collection)

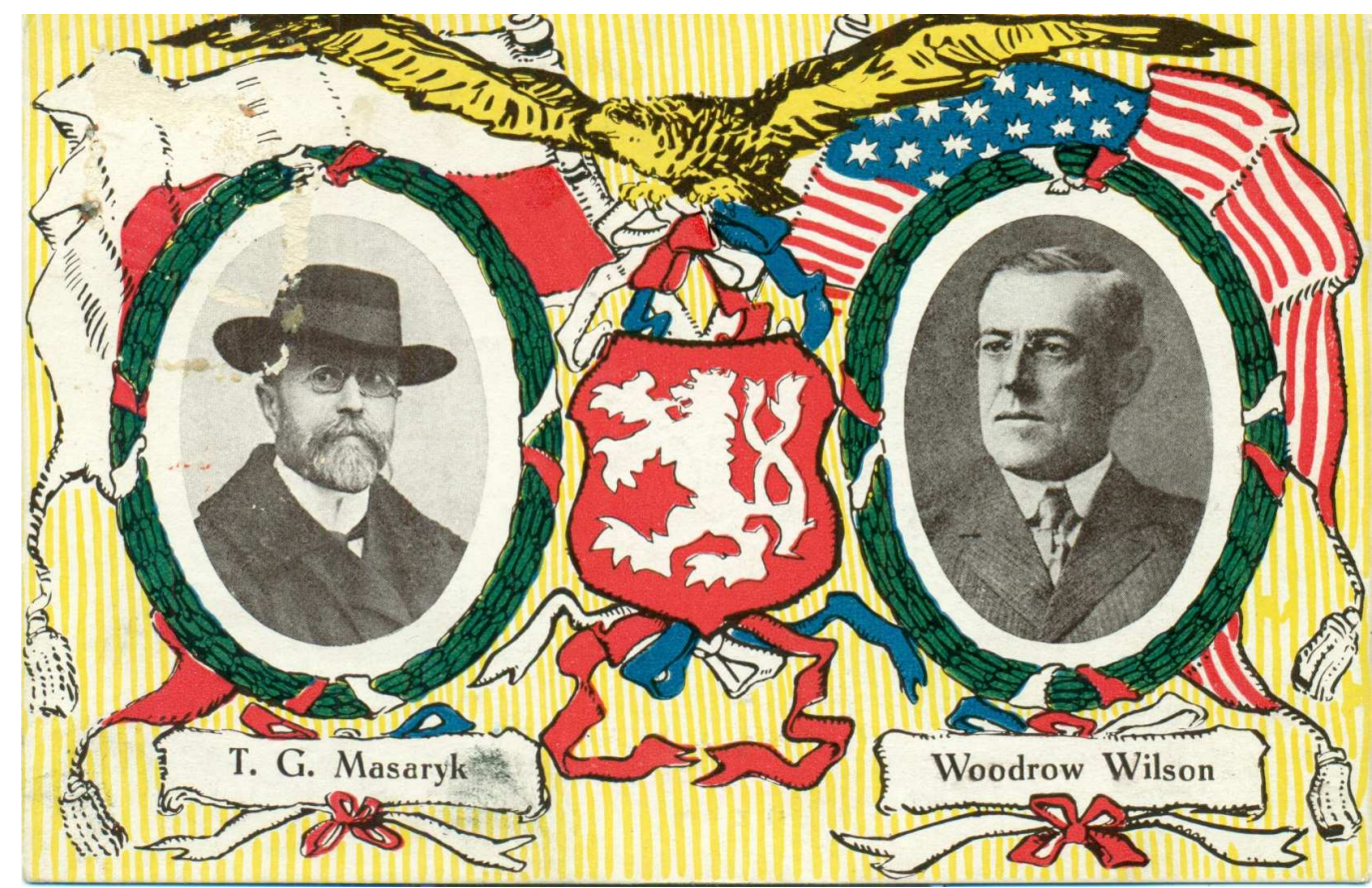

Figure 6 - Tomáš Masaryk and Woodrow Wilson on a Czech postcard commemorating the relationship between the newly formed Czechoslovakia and the United States. (Personal Collection) 


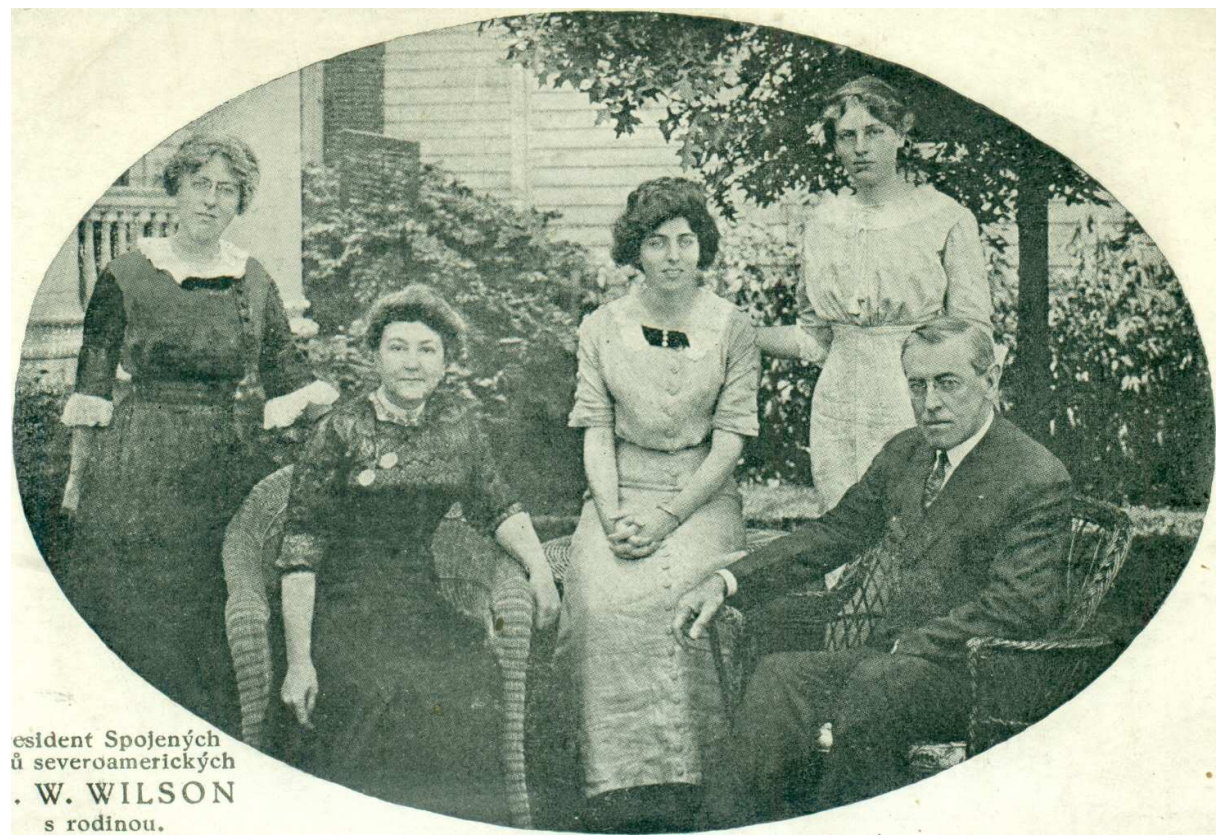

Figure 7 - Woodrow Wilson and family on a Czech postcard (Personal Collection)

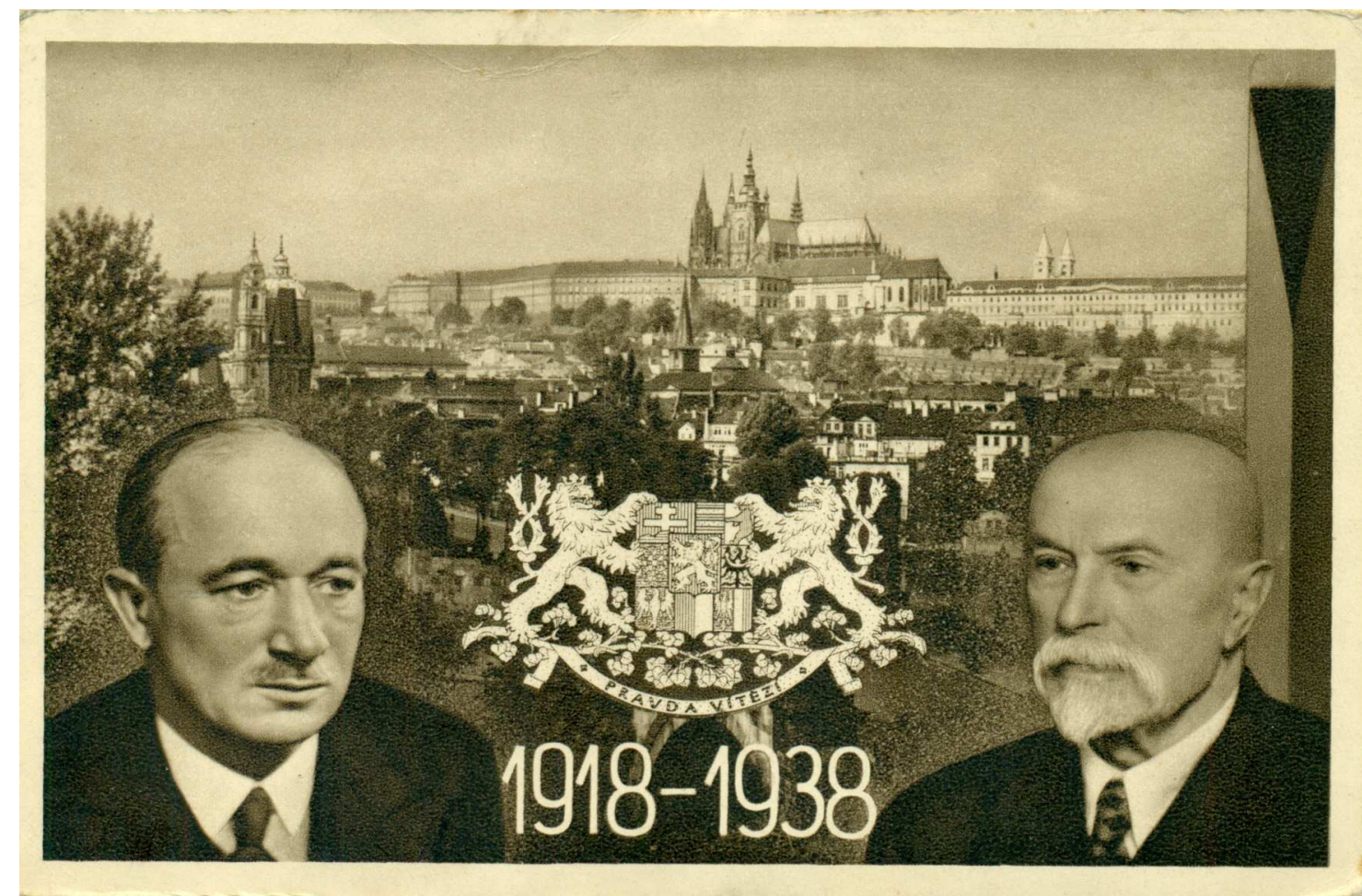

Figure 8 - Edward Benes and Tomáš Masaryk on a Czech postcard after the Nazi takeover of the Czech Republic (Personal Collection) 


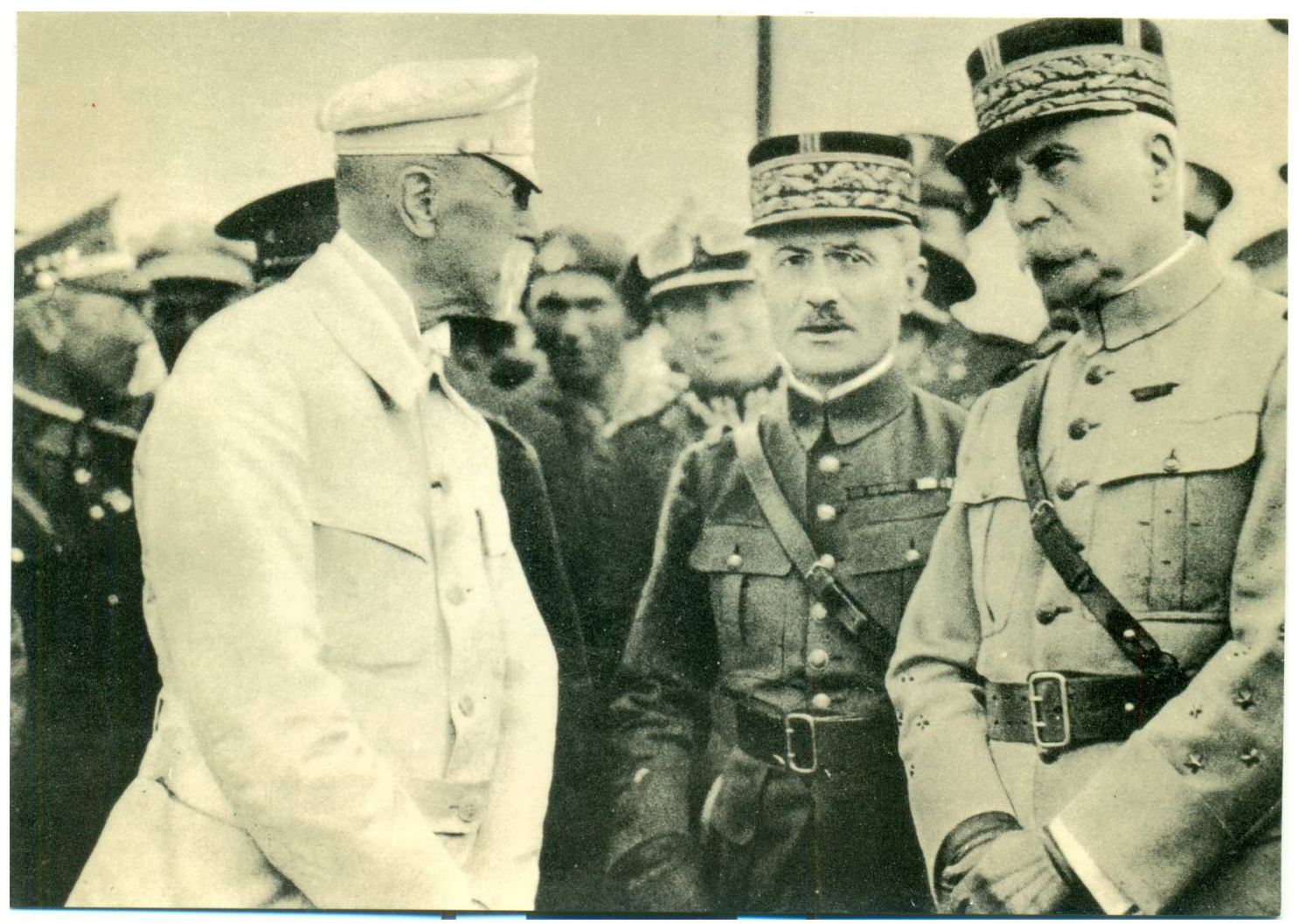

Figure 9 - Tomáš Masaryk (Personal Collection) 


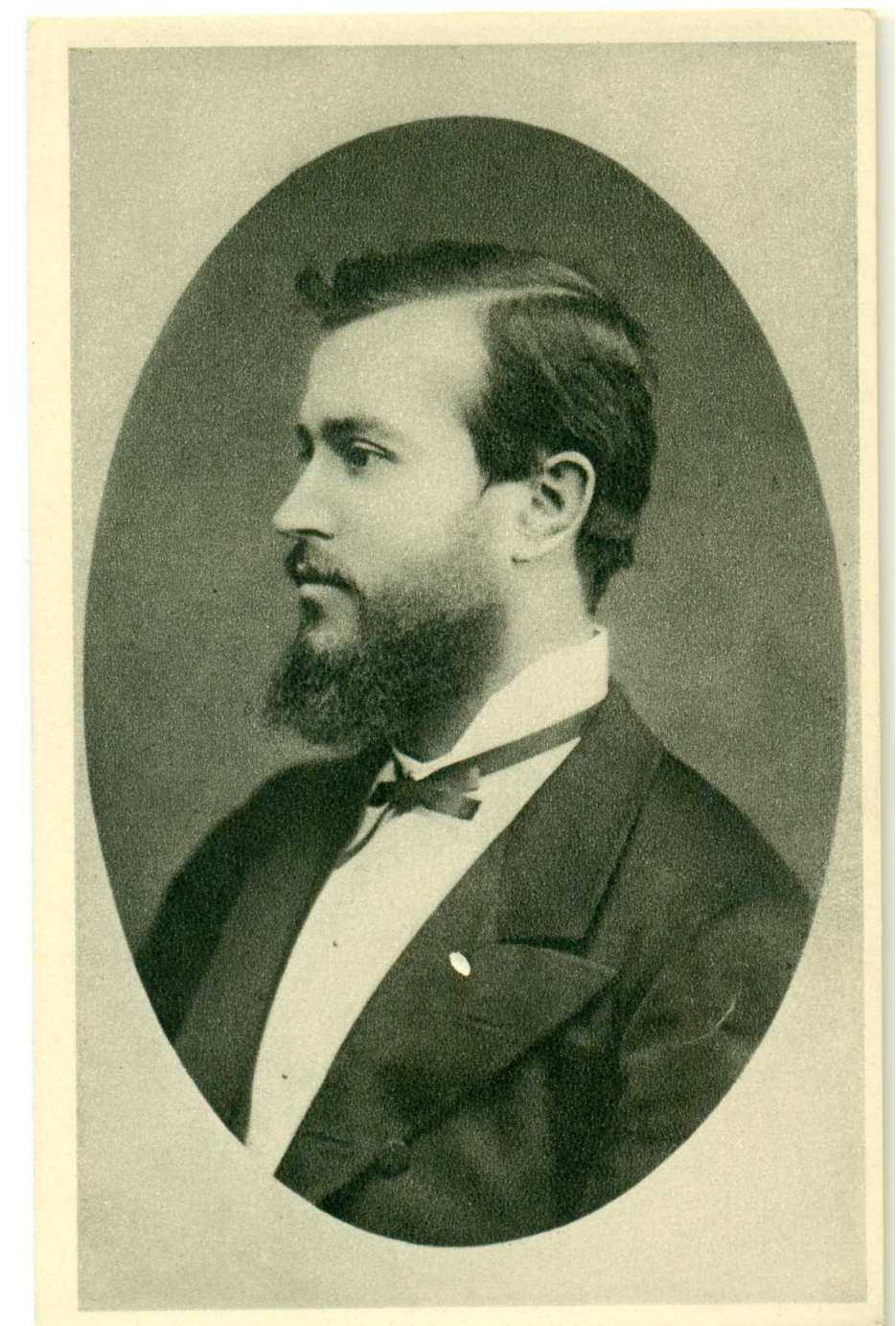

Figure 10 - Tomáš Masaryk as a young man (Personal Collection) 


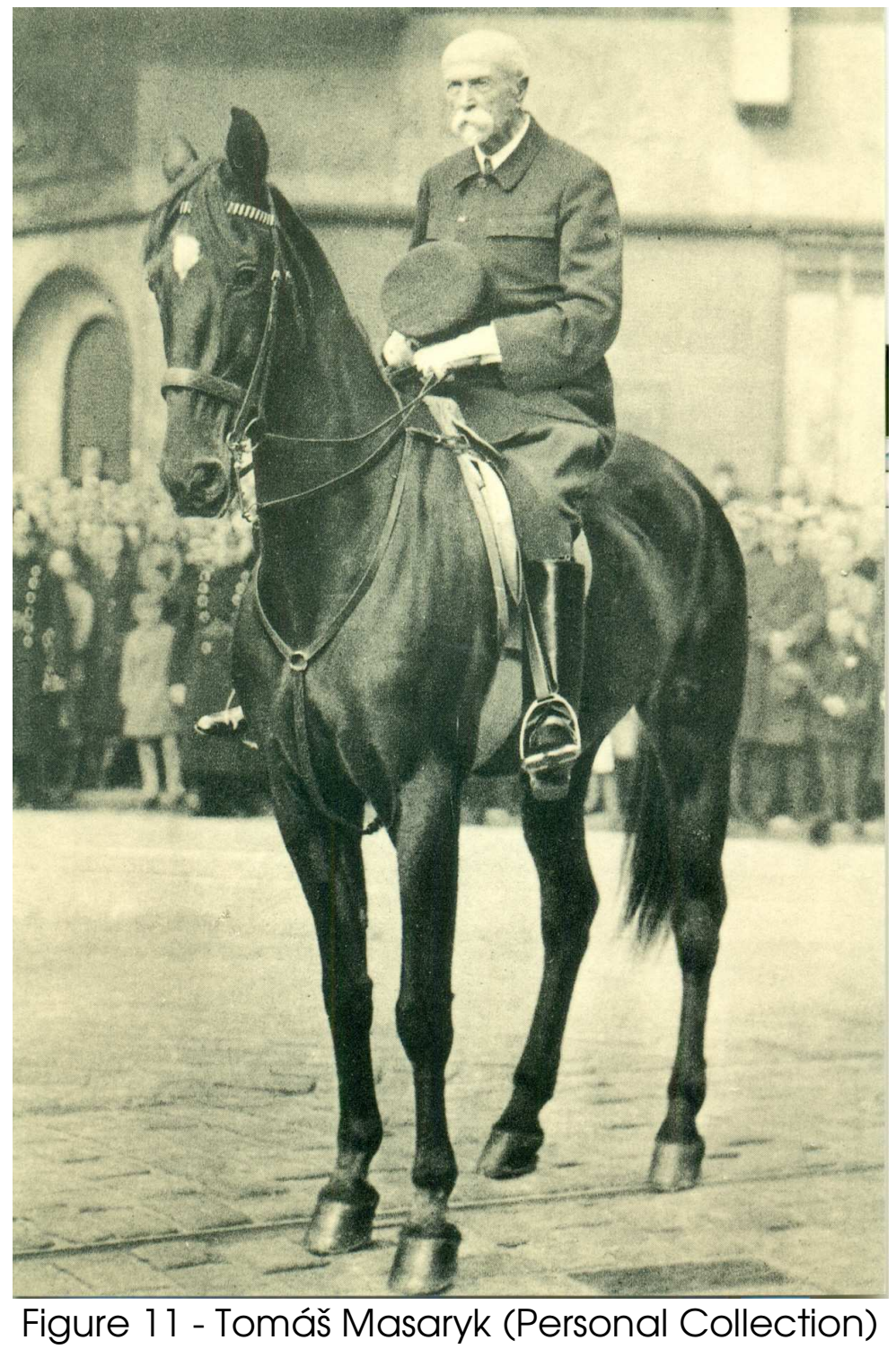




\section{Works Consulted}

\section{Published Primary Sources}

American Friends of the Czech Republic. "Mission." Accessed on January 15, 2014, http://www.afocr.org/mission.

B.C. "The Czech Roots of a Town in Texas." The Economist Blogs. Accessed on January 15, 2014,

http://www.economist.com/blogs/easternapproaches/2013/04/czech-republicand-america.

Beneš, Edvard. Bohemia's Case for Independence. London: G. Allen \& Unwin Ltd., 1917.

Beneš, Edvard. Czechoslovak Policy for Victory and Peace. London: LincolnsPrager Limited, 1944.

Beneš, Edward. Memoirs of Dr. Edward Beneš: From Munich to New War and New Victory. Translated by Godfrey Lias. Boston: Houghton Mifflin Company, 1954.

Beneš, Edward. The Fall and Rise of a Nation: Czechoslovakia 1938-1941. Introduced and Edited by Milan Hauner. Boulder: East European Monographs, 2004.

Capek, Karel. Talks with T.G. Masaryk. North Haven: Catbird Press, 1995.

Daday, Eileen. "Local Czechs Proud of Wilson Statue." The Daily Herald, October 8, 2011.

The Economist Blogs "The Czech Roots of a Town in Texas." Accessed on January 15, 2014, http://www.economist.com/blogs/easternapproaches/2013/04/czech-republicand-america.

Embassy of the Czech Republic in Washington, D.C. "Explosion in West, TxCzech Government Approves Aid." Accessed on January 15, 2014, 
https://www.mzv.cz/washington/en/czech_u_s_relations/news/explosion_at_a_ plant_in_west_tx.html

H. Lansing, H. "Self-Determination." Saturday Evening Post, April 9th, 1921.

Hrobak, Philip. "Czechoslovakism" versus Americanism: An Expose of the ProSoviet "Czechoslovak National Frontiers" in the Council of Free Czechoslovakia." Middletown: Jednota Press, 1953.

Hrobak, Philip. The Slovaks and The Czechs. Slovak League of America, 1954.

Lewis, Brackett. Democracy in Czechoslovakia. New York: American Friends of Czechoslovakia, 1941.

Library of Congress. Background Materials Designed for Use in the Preparation of Statements and Speeches Commemorating Czechoslovak Independence Day (October 23rd) and the Birthday of Czech President Tomáš Masaryk (March 7) (October 4, 1968).

Masaryk, Thomas G. The Meanings of Czech History. Chapel Hill: The University of North Carolina Press, 1974.

Masaryk, Thomas G. The Making of A State: Memories and Observations, 19141918. New York: Frederick A Stokes Company, 1927.

Munzer, Jan and Zdenka Munzer, eds. We Were and We Shall Be: The Czechoslovak Spirit Through the Centuries. New York: Frederick Ungar, 1941.

New York Times. "Czechs Will Unveil Memorial To Wilson." New York Times, July 1, 1928, Special Correspondence.

New York Times. "Prague Dedicates Wilson Monument." New York Times, July 5, 1928, Special Correspondence.

Palm, Matthew J. "Polasek Legacy: Sculptor's Democracy Statue Returns to Prague." Orlando Sentinel, October 3, 2011.

Ravitz, Jessica. "Town Devastated by Fertilizer Explosion is Guided by the West Way." CNN. Accessed on January 15, 2014, 
http://www.cnn.com/2013/04/24/us/west-texas-profile.

Roy, James A. Pole and Czech in Silesia. London: John Lane Company, 1921. http://hdl.handle.net/2027/uc2.ark:/13960/t4gm84q7x.

Sullivan, Patricia. "Prague Honors Woodrow Wilson." The Washington Post, October 6, 2011, Metro section, Suburban edition.

The Czechoslovak Information Service, eds. Czechoslovak Sources and Documents: Speeches of Jan Masaryk in America. Volume 1. New York City: Czechoslovak Information Service, 1942.

The Czechoslovak Information Service, eds. Czechoslovak Sources and Documents: Struggle for Freedom. Volume 2. New York City: Czechoslovak Information Service, 1943.

The Slovak Council. The Slovak Question: A Memorandum submitted by the Slovak Council to Congress of the United States of America. Surrey: Dorling \& Co Ltd., 1940.

United States Department of State. Papers Relating to the Foreign Relations of the United States with the Address of the President to Congress, December 4 , 1917. U.S. Government Printing Office, 1917,

http://digital.library. wisc.edu/1711.dl/FRUS.FRUS1917.

United States Department of State. Papers Relating to the Foreign Relations of the United States, 1918, Supplement 1, The World War, vol. 1. U.S. Government Printing Office, 1918,

http://digital.library. wisc.edu/1711.dl/FRUS.FRUS1918Supp01v01.

Wilson, Woodrow. Life and Letters: Armistice, March 1 -November 11, 1918. Compiled by Ray Stannard Baker. New York: Doubleday, Doran \& Company, Inc., 1939.

Wilson, Woodrow. The Messages and Papers of Woodrow Wilson, edited by Albert Shaw, 2 volumes. New York: The Review of Review Corporation, 1924.

Wolverton, Lisa, trans. Cosmas of Prague: The Chronicle of the Czechs. Washington, DC: The Catholic University of America Press, 2009. 


\section{Published Secondary Sources}

Agnew, Hugh LeCaine. Origins of the Czech National Renascence. Pittsburgh: University of Pittsburgh Press, 1993.

Agnew, Hugh LeCaine. The Czechs and the Lands of the Bohemian Crown. Stanford: Hoover Institution Press, 2004.

Assmann, Aleida. "Four Formats of Memory: From Individual to Collective Constructions of the Past." In Cultural Memory and Historical Consciousness in the German-Speaking World Since 1500, edited by Christian Emden and David Midgley, 19-37. Oxford: Peter Lang, 2004.

Anderson, Benedict. Imagined Communities: Reflections on the Origin and Spread of Nationalism. London: Verso, 2006.

Batonyi, Gabor. Britain and Central Europe: 1918-1933. Oxford: Clarendon Press, 1999.

Bell, Duncan. "Agonistic Democracy and the Politics of Memory." Constellations 15. 1 (2008): 148-166.

Betts, R.R. Essays in Czech History. London: The Athlone Press University of London, 1969.

Borsody, Stephen. The New Central Europe: Triumphs and Tragedies. New York: Columbia University Press, 1993.

Brisch, Hans, and Ivan Volgyes, eds. Czechoslovakia: The Heritage of Ages Past. New York: Columbia University Press, 1979.

Brock, Peter, and $\mathrm{H}$ Gordon Skilling, eds. The Czech Renascence of the Nineteenth Century. Toronto: University of Toronto Press, 1970.

Bryant, Chad. Prague in Black: Nazi Rule and Czech Nationalism. Cambridge: Harvard University Press, 2007.

Gans, Chaim. "The Evaluation of Nationalist Claims to Sovereignty." Political 
Theory 29, no. 1 (February 2001), 58-79.

Chada, Joseph. The Czechs in the United States. Washington D.C.: SVU Press, 1981.

Cisar, Jaroslav. The Role of Czechoslovakia. London, 1944.

Cohen, Gary. The Politics of Ethnic Survival: Germans in Prague, 186 1-1914. Princeton: Princeton University Press, 1981.

Cooper, David L. " Competing Languages of Czech Nation-Building: Jan Kollar and the Melodiousness of Czech," Slavic Review 67, no. 2 (2008): 301-320.

Cornwall, Mark. "The Struggle on the Czech-German Language Border, 18801940." The English Historical Review, 109, no. 433 (1994): 914-951.

Cox, Robert Henry, and Erich G. Frankland. "The Federal State and the Breakup of Czechoslovakia: An Institutional Analysis." Publius, 25, no. 1 (Winter, 1995): 7576.

Crabitès, Pierre. Beneš, Statesman of Central Europe. New York: CowardMcCann Inc, 1936.

Cristescu, Aureliu, comp. The Right to Self-Determination: Historical and Current Development on the Basis of United Nations Instruments. New York: United Nations, 1981.

Dacres, Petrina. "Monument and Meaning." Small Axe 16 (2004): 137-153.

Esposito, David. The Legacy of Woodrow Wilson: American War Aims in World War I. Westport: Praeger Publishers, 1996.

Fawn, Rick, ed. Ideology and National Identity in Post-Communist Foreign Policies. London: Frank Cass Publishers, 2004.

Ference, Gregory. Sixteen Months of Indecision: Slovak American Viewpoints toward Compatriots and the Homeland from 1914 to 1915 as Viewed by the Slovak Language Press in Pennsylvania. Selinsgrove: Susquchanna University Press, 1995. 
Glassheim, Eagle. Noble Nationalists: The Transformation of the Bohemian Aristocracy. Cambridge: Harvard University Press, 2005.

Goldstein, Erik. The First World War Peace Settlements, 1919-1925. London: Pearson Education, 2002.

Hacker, Paul. Slovakia: On the Road to Independence. University Park: The Pennsylvania State University Press, 2010.

Hannan, Kevin. "Language and Ethnicity Among Students in Teschen Silesia." Nationalities Papers 27, no. 2 (1999): 191-203.

Heater, Derek. National Self-Determination: Woodrow Wilson and His Legacy. New York: St. Martin's Press, 1994.

Hempson, Donald. "The Lion with Two Tales: Czechoslovak Economic and Foreign Policy-Making and Its Impact on U.S. Relations, 1919-1929." PhD diss., Ohio State University, 2006.

Hertz, Deborah. How Jews Became Germans: The History of Conversion and Assimilation. New Haven: Yale University Press, 2007.

Heymann, Frederick G. Poland \& Czechoslovakia. New Jersey: Prentice-Hall, 1966.

Hobsbawm, Eric, and Terence Ranger, eds. The Invention of Tradition.

Cambridge: Cambridge University Press, 1992.

Hoff, Joan. A Faustian Foreign Policy from Woodrow Wilson to George W. Bush: Dreams of Perfectibility. Cambridge: Cambridge University Press, 2008.

Horak, Stephan. Eastern European National Minorities 1919-1980: A Handbook. Littleton: Libraries Unlimited Inc, 1985.

Ingrao, Charles W. The Habsburg Monarchy, 1618-1815. New York: Cambridge University Press, 2000.

Ivy, Robert. "Memorials, Monuments, and Meaning." Architectural Record 190.7 (2002): 84. 
Johnson, Lonnie R. Central Europe: Enemies, Neighbors, Friends. New York: Oxford University Press, 2011.

Judson, Pieter M. Guardians of the Nation: Activists on the Language Frontiers of Imperial Austria. Cambridge: Harvard University Press, 2006.

Judson, Pieter M., and Marsha L. Rozenblit, eds. Constructing Nationalities in East Central Europe. New York: Berghahn Books, 2005.

Karski, Jan. The Great Powers \& Poland 1919-1945: From Versailles to Yalta. Lanham: University Press of America, 1985.

Kerner, Robert J, ed. Czechoslovakia: Twenty Years of Independence. Berkeley: University of California Press, 1940.

King, Jeremy. Budweisers into Czechs and Germans: A Local History of Bohemian Politics, 1848-1948. Princeton: Princeton University Press, 2002.

Kissinger, Henry. Diplomacy. New York: Simon \& Schuster, 1994.

Klassen, John M. Warring Maidens, Captive Wives, and Hussite Queens: Women and Men at War and at Peace in Fifteenth Century Bohemia. New York: Columbia University Press, 1999.

Kly, Y.N. and D. Kly, eds. In Pursuit of The Right to Self-Determination: Collected Papers and Proceedings of the First International Conference on the Right to Self-Determination and the United Nations. Atlanta: Clarity Press, 2001.

Korbel, Josef. Twentieth-Century Czechoslovakia: The Meanings of Its History. New York: Columbia University Press, 1977.

Kovtun, George. Masaryk \& America: Testimony of a Relationship. Washington, D.C.: Library of Congress, 1988.

Krejci, Jaroslav. Czechoslovakia, 1918-92: A Laboratory for Social Change. New York: St. Martin's Press, 1996.

Krejci, Oskar. Czechoslovak National Interests: A Historical Survey of 
Czechoslovak National Interests and Reflections on the Demise of Czechoslovak Communism. New York: Columbia University Press, 1996.

Leff, Carol Skalnik. The Czech and Slovak Republics: Nation Versus State. Boulder: Westview Press, 1997.

Levin, Norman Gordon. Woodrow Wilson and World Politics: America's Response to War and Revolution. New York: Oxford University Press, 1968.

Levinson, Sanford. Written in Stone: Monuments in Changing Societies. Durham NC: Duke University Press, 1998.

Lukes, Igor. Czechoslovakia Between Stalin and Hitler: The Diplomacy of Edvard Beneš in the 1930s. New York: Oxford University Press, 1996.

Luza, Radomir, and Victor S. Mamatey, eds. A History of the Czechoslovak Republic: 1918-1948. Princeton: Princeton University Press, 1973.

Lynch, Allen. "Woodrow Wilson and the Principle of 'National SelfDetermination': A Reconsideration." Review of International Studies 28 (2002): 419-436.

Macmillan, Margaret. Peacemakers: The Paris Peace Conference of 1919 and Its Attempt to End War. London: John Murray, 2001.

Mamatey, Victor S. The United States and East Central Europe, 1914-1918: A Study in Wilsonian Diplomacy and Propaganda. Kennikat Press, 1972.

Mason, David S. Revolution and Transition in East-Central Europe. Boulder: Westview Press, 1996.

Miller, Alexi. "Historical Policy: Eastern European Convolutions in the $21^{\text {st }}$ Century." Russia in Global Affairs 4 (2011). Accessed January 2, 2012, http://eng.globalaffairs.ru/number/A-Challenge-from-the-Past-15431.

Miller, Alexei and Maria Lipman, eds. The Convolutions of Historical Politics. Central European Press, 2012.

Mohr, Joan McGuire. The Czech and Slovak Legion in Siberia: 1917-1922. North 
Carolina: McFarland \& Company, 2012.

More, Margaret. The Ethics of Nationalism. Oxford: Oxford University Press, 2001.

Müller, Jan-Werner, ed. Memory and Power in Post-War Europe. Cambridge, 2002.

Murphy, Elizabeth Anne. Initiative Help: United States-Czechoslovak Relations from Versailles to Munich. PhD Diss., Cornell University, 1999.

Neville, Peter. Tomas Masaryk and Eduard Beneš: Czechoslovakia. London: Haus Publishing Ltd, 2010.

Ninkovich, Frank. The Wilsonian Century: U.S. Foreign Policy since 1900. Chicago, The University of Chicago Press, 1999.

O'Grady, Joseph P, ed. The Immigrants' Influence on Wilson's Peace Policies. The University of Kentucky Press, 1967.

O'Keeffe, Tadhg. "Landscape and Memory: Historiography, Theory, Methodology." In Heritage, Memory and the Politics of Identity: New Perspectives on the Cultural Landscape, edited by Niamh Moore and Yvonne Whelan, 3-18. Aldershot, UK: Ashgate, 2006.

Olick, Jeffrey. "Collective Memory: The Two Cultures." Sociological Theory 17.3 (1999), 333-348.

Orzoff, Andrea. Battle for the Castle: The Myth of Czechoslovakia in Europe, 1914-1948. New York: Oxford University Press, 2009.

Paces, Cynthia. Prague Panoramas: National Memory and Sacred Space in the Twentieth Century. Pittsburgh: University of Pittsburgh Press, 2009.

Panek, Jaroslav, and Oldrich Tuma E† Alii. A History of the Czech Lands. Prague: Charles University Press, 2009.

Pearson, Raymond. National Minorities in Eastern Europe: 1845-1945. New York: St. Martin's Press, 1983. 
Pergler, Charles. America in the Struggle for Czechoslovak Independence. Philadelphia, 1926.

Perman, D. The Shaping of the Czechoslovak State: Diplomatic History of the Boundaries of Czechoslovakia, 1914-1920. Netherlands: E.J. Brill, 1962.

Prizel, llya. National Identity and Foreign Policy: Nationalism and Leadership in Poland, Russia and Ukraine. Cambridge: Cambridge University Press, 1998.

Prusin, Alexander V. The Lands Between: Conflict in the Eastern European Borderlands, 1870-1992. Oxford: Oxford University Press, 2010.

Rimek, George. Presidency of Edward Beneš. PhD Diss., University of Ottawa, 1975.

Ronen, Dov. The Challenge of Ethnic Conflict, Democracy and SelfDetermination in Central Europe. London: Frank Cass \& Co Ltd. , 1997.

Rose-Redwood, Ruben. "Collective Memory and the Politics of Urban Space: An Introduction." GeoJournal 73 (2008): 161-164.

Roshwalk, Aviel Roshwald. Ethnic Nationalism and the Fall of Empire: Central Europe, Russia, and the Middle East. New York: Routledge, 2011.

Rothschild, Joseph. East Central Europe between the Two World Wars. Seattle: University of Washington Press, 1983.

Rothschild, Joseph, and Nancy M. Wingfield. Return to Diversity: A Political History of East Central Europe Since World War II. New York: Oxford University Press, 2000.

Roucek, Joseph S. "Czechoslovakia and her Minorities." In Czechoslovakia Twenty Years of Independence, edited by Robert J Kerner, 171-192. Berkeley: University of California Press, 1940.

Sayer, Derek. The Coasts of Bohemia: A Czech History. Princeton: Princeton University Press, 1998.

Schlesinger Jr. , Arthur, ed. The Dynamics of World Power: A Documentary 
History of United States Foreign Policy 1945-1973. New York: Chelsea House Publishers, 1973.

Seton-Watson, Hugh. Eastern Europe Between the Wars: 1918-1941. Hamden: Archon Books, 1962.

Seton-Watson, Hugh. The Eastern European Revolution. New York: Frederick A. Praeger, 1951.

Simek, Milan and Jaroslav Dewetter. Cultural Policy in Czechoslovakia. Paris: UNESCO, 1986.

Smith, Anthony D. National Identity. Reno: University of Nevada Press, 1991.

Smith, Anthony D. "States and Homelands: the Social and Geopolitical Implications of National Territory." Millennium, Journal of International Studies 10, no. 3 (January 1981), 187-202

Smith, Tony. America's Mission: The United States and the Worldwide Struggle for Democracy in the Twentieth Century. Princeton NJ: Princeton University Press, 2012.

Teich, Mikulas, ed. Bohemia in History. Cambridge: Cambridge University Press, 1998.

Unterberger, Betty Miller. "The United States and National Self-Determination: A Wilsonian Perspective." Presidential Studies Quarterly, 26, no. 4 (Fall 1996): 926941.

Unterberger, Betty Miller. The United States, Revolutionary Russia, and the Rise of Czechoslovakia. College Station: Texas A\&M University Press, 2000.

Vojtech, Mastny. The Czechs Under Nazi Rule: The Failure of National Resistance. New York: Columbia University Press, 1971.

Wandycz, Piotr S. Czechoslovak-Polish Confederation and the Great Powers: 1940-43. Bloomington: Indiana University Publications, 1956.

Wandycz, Piotr S. France and Her Eastern Allies 1919-1925: French- 
Czechoslovak-Polish Relations from the Paris Peace Conference to Locarno. Minneapolis: The University of Minnesota Press, 1962.

Wedgwood, C.V. The Thirty Years War. New York: Methuen \& Co., 1987.

Wingfield, Nancy M. Flag Wars and Stone Saints: How the Bohemian Lands Became Czech. Cambridge: Harvard University Press, 2007.

Wolverton, Lisa. Hastening Toward Prague: Power and Society in the Medieval Czech Lands. Philadelphia: University of Pennsylvania Press, 2001.

Zahra, Tara. Kidnapped Souls: National Indifference and the Battle for Children in the Bohemian Lands, 1900-1948. Ithaca: Cornell University Press, 2008.

Zeman, Zbynek. The Masaryks: The Making of Czechoslovakia. London: J.B. Tauris \& Co Ltd. , 1990. 